\title{
GERAKAN PAGUYUBAN PETANI VERSUS NEGARA DAN DAMPAKNYA PADA TINGKAT KESEJAHTERAAN MASYARAKAT DESA SUKAMULYA
}

\author{
The Paguyuban Petani's Movement Versus The State and The Impact to \\ Sukamulya Community's Welfare
}

Dinna Amalia Rahmah*), Endriatmo Soetarto

Departemen Sains Komunikasi dan Pengembangan Masyarakat, Fakultas Ekologi Manusia, Institut Pertanian Bogor

*)Email:dinna.rahmah@gmail.com

\begin{abstract}
Agrarian conflict occurs because of the different of interest between two or more actor to an agrarian source. Agrarian conflict which happen in Desa Sukamulya occurs because of the disagreement between the community and the representative of the state, Lanud Atang Sandjaya TNI-AU. Lanud Atang Sandjaya claims and take over the community's land and make them have to fight back through the Paguyuban Petani movement. This movement's goal is to return the land rights to the community. There are some factors that can make the Paguyuban Petani become a national issue: the leadership, the collectivism, and the activities of the Paguyuban Petani, and the support from other people. This research is to examine the relationship between the Paguyuban Petani's level of success and the community's welfare, either in economic or social. The result shows that Paguyuban Petani has a very weak relationship with the community's economic welfare, but it has a strong enough relationship with the community's social welfare in Sukamulya Village.
\end{abstract}

Keywords: agrarian conflict, paguyuban petani's movement, welfare

\begin{abstract}
ABSTRAK
Konflik agraria terjadi karena perbedaan kepentingan antara dua atau lebih aktor terhadap sumber agraria. Konflik agraria yang terjadi di Desa Sukamulya karena perselisihan antara masyarakat dan perwakilan negara, Lanud Atang Sandjaya TNI-AU. Lanud Atang Sandjaya mengklaim dan mengambil alih tanah masyarakat dan membuat masyarakat harus berjuang kembali melalui gerakan Paguyuban Petani. Tujuan dari gerakan ini adalah untuk mengembalikan hak atas tanah kepada masyarakat. Ada beberapa faktor yang dapat membuat Paguyuban Petani menjadi isu nasional seperti : kepemimpinan, kolektivisme, dan kegiatan Paguyuban Petani, serta dukungan dari orang lain. Penelitian ini bertujuan untuk menguji hubungan antara tingkat Paguyuban Petani yang sukses dan kesejahteraan masyarakat, baik di bidang ekonomi maupun sosial. Hasil penelitian menunjukkan bahwa Paguyuban Petani memiliki hubungan yang sangat lemah dengan kesejahteraan ekonomi masyarakat, tetapi memiliki hubungan yang cukup kuat dengan kesejahteraan sosial masyarakat di Desa Sukamulya.
\end{abstract}

Kata kunci: gerakan paguyuban Petani, kesejahteraan, konflik agraria

\section{PENDAHULUAN}

Agraria mempunyai definisi yang sangat luas. UndangUndang Pokok Agraria (UUPA) No. 5 tahun 1960 mendefinisikan agraria sebagai seluruh bumi, air, dan ruang angkasa, termasuk kekayaan alam yang terkandung didalamnya. Jadi, dapat dikatakan bahwa lahan termasuk ke dalam kategori bumi dan merupakan bagian dari agraria. Indonesia sebagai negara agraris, tentunya memiliki potensi yang besar dalam hal agraria terutama bidang pertanian. Badan Pusat Statistik (BPS 2010) dalam sensus penduduk tahun 2010 menyatakan bahwa jumlah masyarakat Indonesia yang berumur lebih dari 15 tahun paling banyak bekerja di sektor pertanian tanaman padi dan palawija dibandingkan dengan sektor lainnya. Jumlah tersebut sebesar 25880441 orang atau hampir mencapai 25 persen dari total penduduk berusia lima belas tahun yang bekerja. Hal ini menjadi penjelasan bahwa pertanian masih menjadi lapangan pekerjaan "primadona" di Indonesia. Oleh karena itu, tidak heran bahwa lahan pertanian menjadi sangat penting keberadaannya bagi kalangan petani.

Dewasa ini muncul berbagai macam kasus yang bersumber pada ketimpangan dalam hal penguasaan sumber-sumber agraria. Ketimpangan penguasaan inilah yang akan memunculkan konflik yang bernama konflik agraria. Gunawan Wiradi mengatakan bahwa konflik terjadi ketika satu atau dua individu dan kelompok yang saling berebut sebuah objek (Luthfi et al. 2010). Menurut Mahkamah Agung (MA), data empiris sengketa mengenai pertanahan di Indonesia cukup tinggi dibandingkan dengan sengketa lain dalam perkara perdata, baik di pengadilan tingat 
pertama maupun yang telah masuk ke MA. Rata-rata perkara perdata bidang pertanahan yang ditangani MA (2001-2005) tercatat 63 persen dari perkara perdata yang masuk ke MA. Kemudian data statistik permasalahan pertanahan yang saat ini ditangani Badan Pertanahan Nasional RI setelah validasi bulan Agustus 2007, diketahui terdapat 7491 kasus, dengan rincian sengketa pertanahan 4581 kasus, konflik pertanahan 858 kasus, serta kasus perkara pertanahan sebanyak 2052 kasus (Setiawan, 2007).

Salah satu tujuan pokok dari UUPA tahun 1960 adalah menjadi dasar dalam mewujudkan kepastian hukum mengenai hak-hak atas tanah bagi seluruh rakyat Indonesia. Tetapi justru munculnya konflik yang semakin meningkat membuktikan bahwa telah terjadi pengingkaran atas UUPA tersebut. Konflik agraria dalam hal pertanahan berarti perebutan makanan dan perebutan tiang hidup manusia. Untuk itu, orang rela menumpahkan darah, mengorbankan segala yang ada demi mempertahankan hidup selanjutnya (Tauchid, 2009). Tak jarang petani yang merasa terpojokkan akhirnya akan melakukan perlawanan terhadap pihak lain yang berebut kepentingan dengannya. Hal inilah yang akan menimbulkan sebuah gerakan perlawanan petani. Gerakan perlawanan petani menjadi suatu fenomena yang menarik untuk diteliti karena muncul sebagai sebuah akibat dari pengingkaran atas UUPA.

Desa Sukamulya merupakan sebuah desa yang berada di Kecamatan Rumpin, Kabupaten Bogor. Sejak tahun 2007, di desa ini muncul sebuah konflik agraria yang sampai saat ini masih mengalami proses penyelesaian. Konflik agraria terjadi antara masyarakat terutama petani yang berhadapan dengan negara yang diwakili oleh Lanud Atang Senjaya TNI-AU (untuk selanjutnya disebut Lanud ATS). Tanah adalah objek agraria yang diperebutkan dalam kasus ini. Lanud ATS mengklaim tanah masyarakat sebagai tanah negara sehingga mereka mengambilnya dengan dalih untuk kepentingan TNI-AU, seperti perluasan lapangan udara, tempat latihan water training, dan perumahan khusus anggota TNI-AU. Pengambilalihan dan pengklaiman tanah yang dilakukan Lanud ATS dengan cara pemaksaan ini akhirnya memarjinalkan masyarakat Desa Sukamulya dari tanah mereka.

Hal inilah yang memicu munculnya gerakan perlawanan dari masyarakat Desa Sukamulya. Pada akhirnya masyarakat membentuk sebuah Paguyuban Petani dalam rangka untuk mempertahankan tanah mereka. Kemudian gerakan perlawanan petani yang dilakukan oleh masyarakat Desa Sukamulya diduga akan mempunyai pengaruh terhadap kehidupan mereka terutama dilihat dari sisi tingkat kesejahteraan masyarakat. Oleh karena itu, peneliti ingin melihat dampak dari gerakan perlawanan ini terhadap tingkat kesejahteraan masyarakat Desa Sukamulya.

\section{Masalah dan Kegunaan Penelitian}

Berdasarkan latar belakang yang telah dipaparkan, maka masalah penelitian yang dikemukakan antara lain:

1. Bagaimana bentuk gerakan perlawanan yang berwujud di Desa Sukamulya?

2. Bagaimana caranya Paguyuban Petani menciptakan situasi untuk mendapatkan jaminan kepastian kontrol atas tanah miliknya?

3. Bagaimana dampak gerakan Paguyuban Petani terhadap tingkat kesejahteraan masyarakat dari sisi ekonomi dan sosial?

Penelitian ini diharapkan dapat memberikan manfaat bagi 3 pihak, yaitu akademisi sebagai bahan referensi dan kajian untuk penelitian selanjutnya, pemerintah sebagai bahan referensi dan pertimbangan untuk menyusun dan membuat kebijakan atau keputusan tentang pemanfaatan lahan dan konflik agraria, dan masyarakat khususnya warga Desa Sukamulya sebagai bahan penambah wawasan dan tambahan bukti untuk memperjuangkan hak-hak atas tanah mereka.

\section{PENDEKATAN TEORITIS}

\section{Tinjauan Pustaka}

Sjaf (2010) dalam tulisannya mengenai "Batasan Definisi Petani" menyatakan bahwa petani tergolong menjadi dua yaitu peasant dan farmer. Perbedaan antara kedua sebutan untuk petani ini dapat dilihat dari sifat usaha pertanian mereka secara sosial-ekonomi-politik-budaya. Sifat usaha pertanian peasant berupa pengolahan lahan dengan bantuan keluarga sendiri untuk menghasilkan bahan makanan bagi keperluan hidup sehari-hari keluarga petani tersebut (cara hidup subsisten). Sebaliknya petani farmer melakukan pengolahan lahan pertanian dengan bantuan tenaga buruh tani, dan mereka menjalankan produksi dalam rangka untuk mencari keuntungan dengan cara hasil produksi pertanian mereka dijual ke pasar untuk memperoleh uang kontan.

Petani di Negara Indonesia jika digolongkan menurut jumlah lahan yang dikuasai maka dapat digolongkan menjadi empat golongan besar, yaitu petani besar, petani kecil, petani gurem, dan petani buruh atau buruh tani (Sastraatmadja, 2010). Petani besar umumnya menggambarkan tentang sosok petani yang memiliki lahan sawah di atas $1 \mathrm{Ha}$. Petani kecil menggambarkan jati diri petani yang memiliki lahan $0,5-1 \mathrm{Ha}$. Petani gurem memiliki lahan antara $0,1-0,5$ Ha. Terakhir ialah petani buruh atau buruh tani adalah mereka yang sama sekali tidak memiliki lahan sawah.

Sajogyo dalam Luthfi (2011) menunjukkan siapa rakyat dengan merujuk kepada Sistem Neraca Sosial Ekonomi Nasional (SNSE) dari BPS dengan cara membedakan "pertanian" dan "bukan-pertanian". Dari kelompok "pertanian", terdapat 3 golongan: petani gurem (memiliki tanah kurang dari 0,5 Ha) yang berjumlah 34 persenn; buruh tani 37 persen; dan petani bukan gurem 26 persen (pada tahun 1978). Dua kelompok pertama itulah yang sejatinya disebut sebagai "rakyat". Kelompok yang bukan gurem berpotensi di dalam aktivitas bukan pertanian dan meningkat menjadi farmer. Pandangan Sajogyo ini menyatakan bahwa "rakyat" yang sesungguhnya adalah petani peasant dengan luas lahan yang sempit dan mengusung prinsip subsisten dalam kehidupan sehariharinya. Sedangkan untuk petani dengan lahan yang luas, Sajogyo menyebutnya dengan sebutan farmer yang berorientasi pada penjualan hasil produksi pertanian untuk mendapatkan keuntungan.

Gunawan Wiradi menyatakan bahwa konflik terjadi ketika satu atau dua individu dan kelompok yang saling berebut sebuah objek (Luthfi et al. 2010). Objek yang dimaksud tentulah sumber-sumber agraria yang salah satunya ialah tanah seperti yang telah disebutkan sebelumnya. Proses 
interaksi yang terjadi antar individu atau kelompok yang saling mendahului dalam hal berebut objek-objek agraria, maka sifatnya masih dalam batas "persaingan". Tetapi apabila mereka saling berhadapan satu sama lain untuk menghalangi atau memblokir jalan lawan maka saat itulah muncul situasi konflik. Hal inilah yang Hoult dalam Wiradi (2009) tekankan bahwa konflik adalah bentuk ekstrem dan keras dari persaingan.

Jika konflik agraria dibagi berdasarkan aktor maka konflik terbagi menjadi konflik vertikal dan konflik horizontal. Konflik vertikal terjadi antara pihak dengan stratifikasi sosial yang rendah dengan stratifikasi sosial yang lebih tinggi, misalnya antara petani dengan pemerintah atau perusahaan swasta. Konflik horizontal terjadi antara dua pihak yang mempunyai stratifikasi sosial yang sama, misalnya yang terjadi antar dua masyarakat adat. Kemudian jika konflik agraria dibagi berdasarkan bentuknya maka terbagi atas konflik tertutup, konflik mencuat dan terbuka (Fuad dan Maskanah, 2000). Konflik tertutup atau laten pada umumnya belum terjadi kontak fisik antar pihak yang berkonflik. Bentuk dari konflik laten ini belum terlihat secara jelas dan masih berupa isu-isu atau gosip. Konflik mencuat adalah saat pihak-pihak yang berkonflik telah teridentifikasi serta adanya perselisihan dan permasalahan yang jelas tetapi belum ada pengembangan penyelesaiannya. Konflik terbuka adalah konflik dimana sudah terjadi kontak fisik antar pihak yang berkonflik. Masing-masing pihak sudah menyatakan diri secara terbuka bahwa mereka sedang berkonflik.

Konflik agraria juga dapat disebabkan oleh adanya ketimpangan agraria antar kedua aktor agraria atau lebih. Wiradi (2009) menyatakan bahwa sedikitnya ada empat bentuk ketimpangan agraria. Pertama ialah ketimpangan dalam hal penguasaan sumber-sumber agraria. Kedua ialah ketidakserasian dalam hal "peruntukan" sumber-sumber agraria. Ketiga ialah ketidakserasian antara persepsi dan konsepsi mengenai agraria. Terakhir ialah ketidakserasian antara berbagai produk hukum, sebagai akibat dari pragmatisme dan kebijakan sentral.

Ada tiga kelompok yang biasanya tercakup dalam masalah agraria, yaitu pemerintah, pengusaha (BUMN dan BUMS), dan masyarakat (Wiradi, 2009). Pada umumnya masyarakat yang terlibat dalam konflik agraria adalah masyarakat yang mempertahankan objek agraria berupa lahan yang mereka miliki. Swasta pada umumnya berupa perusahaanperusahaan besar yang berkepentingan terhadap suatu objek agraria. Mereka memiliki modal yang besar dalam usaha tersebut sehingga seringkali menggunakan berbagai cara untuk mendapatkan objek atau sumber agraria. Peran pemerintah menjadi sangat penting dalam diagram hubungan aktor-aktor agraria. Pemerintah mempunyai hak legal untuk mengatur berbagai kepentingan di negara ini, termasuk kepentingan menyangkut agraria. Sebagai "pemilik" negara, setiap orang yang ingin mengusahakan suatu objek atau sumber agraria secara legal harus memperoleh izin terlebih dahulu dari pemerintah.

Konflikagrariaakanmenyebabkanmasyarakatterpinggirkan atau termarjinalisasi dari tanah miliknya. Tanah atau lahan yang menjadi objek konflik agraria akan dibekukan status kepemilikannya. Hal ini akan terus berlanjut sampai terdapat keputusan yang legal dari pemerintah mengenai status lahan tersebut. Biasanya yang memenangkan hak kepemilikan atas lahan dalam konflik agraria adalah negara itu sendiri atau pihak swasta. Marjinalisasi masyarakat ini akan menyebabkan kemiskinan yang semakin terlihat jelas baik dalam konteks pedesaan maupun perkotaan. White dan Wiradi (2009) menyatakan bahwa daerah pedesaan semakin memperlihatkan meningkatnya ketidaksetaraan dalam hal stratifikasi sosial, yaitu antara golongan petani kaya dan sejumlah keluarga petani tak bertanah disisi lain. Kesempatan kerja dalam bidang pertanian tidak lagi cukup untuk menyediakan nafkah bagi para petani tak bertanah dan marjinal itu.

Landsberger dan Alexandrov (1974) mengatakan bahwa yang dimaksud dengan sebuah gerakan ialah setiap reaksi kolektif terhadap kedudukan rendah dari petani itu sendiri. Secara khusus, dalam dalam menganalisis gerakan perlawanan petani terdapat empat dimensi yang harus diperhatikan yaitu tingkat kesadaran, tingkat kolektifitas aksi, orientasi instrumental, dan status rendah sebagai basis gerakan. Dimensi pertama ialah tingkat kesadaran. Peranan konsep "kesadaran" dalam gerakan-gerakan petani jelas akan sangat penting. Marx dan Engels, serta Lenin adalah para pemikir yang paling jelas mengakui bahwa adanya suatu gerakan dan khususnya hakikat dari sasaran gerakan adalah berhubungan erat dengan kesadaran dari anggotaanggotanya. Lebih lanjut, bahwa kesadaran itu problematis sifatnya. "Pemiskinan" yang bisa diharapkan dari kompetisi kapitalis dan krisis yang semakin dalam ini akan membuat kaum tani sadar akan persamaan nasib dan musuh bersama mereka. Penelitian yang dilakukan oleh Setiawan (2012) menyebutkan bahwa salah satu faktor yang mempengaruhi keberhasilan organisasi petani ialah kepemimpinan. Dalam upaya meningkatkan kesadaran masyarakat dibutuhkan seorang pemimpin dalam suatu gerakan sosial. Pemimpin tersebut juga yang akan menjadi salah satu indikator keberhasilan dalam sebuah gerakan sosial.

Kedua ialah kolektifitas aksi, dimana petani saling tergabung dalam kebersamaan untuk mencapai tujuan yang mereka inginkan. Puncak dari dimensi ini ialah terjadinya koordinasi pembagian tugas dan kerja serta wewenang tidak hanya di kelompok keluarga tetapi juga beberapa kelompok sederhana. Ketiga ialah perilaku orientasi instrumental yang merupakan kata sifat yang dilekatkan bila suatu perkumpulan atau gerakan mengejar sasaran yang terletak di luar kegiatan langsung mereka. Kegiatankegiatan di luar dilakukan untuk mencapai hasil akhir yang mereka capai. Dalam konteks gerakan perlawanan petani, tujuan yang ingin dicapai ialah perubahan dalam penguasaan tanah.

Terakhir ialah dimensi status rendah sebagai basis gerakan. Status yang rendah ini mendorong mereka untuk melakukan perubahan melalui sebuah gerakan melawan. Mereka ingin menjadikan dirinya berkedudukan dan berstatus yang sama dengan aktor lainnya dalam hal penguasaan sumber agraria. Penelitian yang dilakukan oleh AGRA (2010), Taib et al. (2010), serta Fermata (2006) menunjukkan bahwa ada beberapa pihak yang turut serta membantu masyarakat dalam upaya meningkatkan rasa kepercayaan diri mereka.

Tidak hanya itu, pihak-pihak ini juga membantu petani dalam menyuarakan konflik agraria yang telah mereka alami. Umumnya, pihak-pihak ini adalah organisasi di luar badan pemerintahan seperti organisasi mahasiswa, maupun organisasi kemasyarakatan lainnya terutama organisasi hak asasi manusia dan organisasi agraria. Oleh karena itu, penting untuk melihat keberadaan pihak lain dalam konteks 
gerakan perlawanan petani.

Ada banyak bentuk jenis gerakan perlawanan petani, baik yang teroganisir ataupun spontan, baik yang dilakukan secara diam-diam maupun radikal. Pada umumnya bentuk gerakan perlawanan petani terbagi atas tiga bentuk, yaitu perlawanan sehari-hari, perlawanan sekali-kali, dan perlawanan masif (Soetarto E, 17 Juni 2013, komunikasi pribadi). Perlawanan sehari-hari ialah perlawanan yang dilakukan petani dalam kesehariannya. Misalnya saja petani yang menggarap diam-diam di atas lahan konflik. Penggarapan ini dilakukan tanpa diketahui oleh pihak yang berkonflik dengan petani. Kemudian perlawanan sekalikali dilakukan secara insidental apabila ada suatu kejadian yang memaksa petani untuk melakukan perlawanan. Terakhir ialah perlawanan masif ialah perlawanan yang dilakukan secara kontinyu atau terus-menerus. Biasanya perlawanan ini dilakukan dengan perencanaan sebelumnya dan semakin lama akan semakin besar apabila petani masih tidak ditanggapi oleh pemerintah atau pihak swasta yang berkonflik.

Landsberger dan Alexandrov (1974) memberikan sebuah penjelasan mengenai perkembangan perlawanan petani. Pada awalnya petani bersikap spontan dengan tuntutan awal yang bersifat spesifik dan terbatas mengenai situasi mereka sendiri daripada mencakup perubahan yang menjangkau seluruh masyarakat dan tidak terlalu radikal. Secara logika dalam konteks perlawanan petani, pada awalnya petani dengan kehidupan yang sederhananya hanya akan melakukan aksi protes yang biasa-biasa saja.

Kemudian saat aksi tersebut tidak dijejakpendapatkan oleh aktor agraria lain seperti pemerintah atau perusahaan swasta, maka petani akan menggunakan cara yang lebih keras dan radikal dengan harapan aktor agraria lainnya akan memperhatikan kehidupan mereka. Tetapi seiring dengan perkembangan zaman, petani pedesaan menjadi lebih terbuka dan mampu untuk menerima perubahan dari luar maka petani tersebut akan berpikiran lebih maju. Hal inilah yang membuat jenis-jenis gerakan perlawanan petani menjadi lebih beragam pada saat ini.

Penelitian yang dilakukan oleh Setiawan(2012) menemukan bahwa strategi petani bergeser dari "konfrontatif" menjadi "kolaboratif" disebabkan karena munculnya kebijakan agraria baru yang telah membuka ruang, peluang, dan kesempatan bagi petani untuk berpendapat. Faktor-faktor internal yang mempengaruhinya antara lain kepemimpinan petani yang cenderung terbuka dan memanfaatkan ruang politik, ketaatan kader, dan anggota terhadap pemimpinnya, faktor kepercayaan dari terhadap pembuat kebijaksanaan agraria, faktor keyakinan tujuan akan lebih cepat tercapai, dan faktor kebutuhan anggota untuk memperoleh berbagai sarana hidup. Selain itu, faktor-faktor eksternal yang ikut mempengaruhi antara lain adanya kebijakan agraria dari Badan Pertanahan Nasional (BPN), tersedianya informasi mengenai kebijakan reforma agraria, komunikasi yang efektif, intensifnya pendampingan, serta dukungan sosial dan politik dari elit pemerintahan.

Semakin lama gerakan perlawanan yang dilakukan oleh petani semakin berkembang dan semakin "halus" sehingga tidak lagi terlihat sebagai perlawanan yang radikal. Purwandari (2006) dalam penelitiannya melahirkan konsep "perlawanan tersamar" sebagai sebuah adaptasi terhadap perkembangan tipe musuh. Konsep ini merupakan gabungan antara upaya mempertahankan kemapanan sosial dan melakukan dekonstruksi sosial.

Petani sekarang melakukan perlawanan tersamar dengan cara melakukan kegiatan-kegiatan yang sesuai dengan program pemerintah pada bidang pertanian tetapi sedikit "diselewengkan" dengan cara mengubah program tersebut sesuai dengan kebutuhan masyarakat. Dengan demikian, maka pemerintah tidak akan melakukan perlawanan kembali karena aksi-aksi yang dilakukan petani sesuai dengan program pemerintah. Pada tingkatan perlawanan tersamar ini, umumnya petani lebih rasional dan sudah mengerti bagaimana cara melawan tanpa harus menimbulkan konflik yang lebih parah lagi atau korban jiwa.

Konflik agraria terbukti mampu untuk menurunkan tingkat kesejahteraan petani baik secara ekonomi maupun secara sosial. Berdasarkan hasil penelitian dari Wiradi dan Makali (2009) terdapat kesimpulan bahwa walaupun seorang tunakisma (petani tanpa lahan) dapat menguasai tanah melalui penyakapan (bagi hasil, sewa menyewa, dan sebagainya) dan pemilik menjadi bukan penggarap. Namun, baik secara langsung atau tidak langsung pemilikan tanah merupakan faktor yang turut menentukan tingkat hidup di pedesaan.

Definisi dari kesejahteraan sendiri telah dilahirkan dari beragam peneliti dari dahulu maupun sampai sekarang. Di Indonesia, dalam pasal 1 yang tercantum dalam UndangUndang Republik Indonesia Nomor 11 tahun 2009 tentang kesejahteraan sosial, dinyatakan bahwa yang dimaksud dengan kesejahteraan sosial adalah kondisi terpenuhinya kebutuhan material, spiritual, dan sosial warga negara agar dapat hidup layak dan mampu mengembangkan diri, sehingga dapat melaksanakan fungsi sosialnya. Selain itu Badan Kependudukan dan Keluarga Berencana Nasional (BKKBN) tahun 2011 merumuskan bahwa konsep dari keluarga sejahtera adalah keluarga yang dibentuk berdasarkan atas perkawinan yang sah, mampu memenuhi kebutuhan hidup spiritual dan materiil yang layak, bertaqwa kepada Tuhan Yang Maha Esa, memiliki hubungan yang serasi, selaras dan seimbang antar anggota dan antar keluarga dengan masyarakat dan lingkungan. Inti dari kesejahteraan sosial itu sendiri ialah terpenuhinya kebutuhan baik secara moril maupun materiil. Secara umum, tingkat kesejahteraan seseorang dapat diukur dari bidang ekonomi, sosial, politik, dan lingkungan alam.

Penelitian Tim Rises Sistematis (2009) menyebutkan bahwa untuk mengukur tingkat kesejahteraan petani dapat dilihat dari berbagai indikator. Indikator dari penelitian ini yakni kepemilikan aset berupa rumah, lahan, ternak, harta benda dan simpanan emas. Selain itu, dalam sisi ekonomi juga dapat dilihat dampak dari gerakan perlawanan petani terhadap tingkat kesempatan kerja dan tingkat pendapatan. Hal ini disebabkan marjinalisasi petani dari lahan garapan akan memisahkan mereka dari sumber pendapatannya, sehingga terjadi perubahan dari aspek kesempatan kerja maupun pendapatan petani. Jadi, perlu dilihat dampak dari gerakan perlawanan petani ini terhadap kedua hal tersebut.

Lebih lanjut, ada sekiranya tiga hal masalah yang sering dihadapi oleh petani berupa masalah internal, psikologis sampai masalah fisik yang merugikan petani berupa (1) kriminalisasi tokoh petani; (2) reclaiming tanah dari pihak luar atau penguasa serta; (3) adanya berbagai isu negatif dan teror psikologis (Soetarto E, 16 Desember 2013, 
komunikasi pribadi). Kesejahteraan dalam bidang sosial dapat dilihat dari tingkat kriminalisasi yang dialami oleh petani. Selain itu gerakan perlawanan petani juga akan berdampak pada hubungan-hubungan yang terjadi di dalam masyarakat, baik hubungan antar masyarakat itu sendiri, maupun hubungan masyarakat dengan pihak lain yang berkonflik.

Tetapi tidak semua gerakan perlawanan petani dapat mengembalikan kesejahteraan petani yang terenggut. Gerakan ini juga dapat menimbulkan kemerosotan yang lebih dalam lagi. Hartoyo (2010) menyebutkan bahwa gerakan perlawanan petani dapat mengalami kemacetan. Hal ini disebabkan munculnya penyimpanganpenyimpangan dalam perilaku aktor itu sendiri. Perpecahan antar petani dapat saja timbul dan justru menimbulkan konflik horizontal diantara petani sendiri. Selain itu, hubungan petani dengan aktor "atas" dapat juga menjadi buruk sehingga semakin kecil kemungkinan petani dapat berperan dalam memperjuangkan nasibnya. Memburuknya hubungan baik antar petani maupun antara petani dan aktor lainnya dapat menurunkan performa gerakan perlawanan petani itu sendiri. Tingkat kesejahteraan ekonomi dapat dilihat dari hasil yang didapatkan dari pekerjaan maupun aset-aset fisik yang dimiliki oleh petani. Lalu tingkat kesejahteraan sosial dapat ditinjau dari sisi hubunganhubungan antar aktor itu sendiri yang berdampak pada kehidupan petani.

\section{Kerangka Penelitian}

Salah satu kasus yang terjadi ialah kasus sengketa tanah antara masyarakat Desa Sukamulya dengan Lanud Atang Senjaya TNI-AU (untuk selanjutnya disebut Lanud ATS) di Kecamatan Rumpin, Kabupaten Bogor. Lanud ATS mengklaim sejumlah tanah yang cukup luas di Desa Sukamulya, dimana tanah tersebut adalah lahan garapan maupun permukiman dari masyarakat setempat. Lahan tersebut akan digunakan sebagai tempat water training bagi para anggota TNI-AU. Hal inilah yang memicu munculnya konflik antara masyarakat Desa Sukamulya dengan pihak Lanud ATS. Konflik ini membuat masyarakat tersingkir dari lahan pertanian dan pemukiman mereka.

Masyarakat yang tersingkir ini melakukan gerakan perlawanan petani yang berwujud Paguyuban Petani. Gerakan dari Paguyuban ini dapat dilihat dari kepemimpinan yang melingkupinya, kolektifitas petani, kegiatan yang dilakukan, dan bantuan dari pihak lain. Gerakan ini diperkirakan mampu untuk menciptakan situasi dimana masyarakat mempunyai jaminan kepastian kontrol atas sumber-sumber nafkah mereka yaitu lahan yang diklaim oleh Lanud ATS. Adanya situasi ini, gerakan perlawanan petani diperkirakan mempunyai hubungan dengan tingkat kesejahteraan mereka baik dilihat dari sisi ekonomi maupun sisi sosial. Sisi ekonomi dapat dilihat dari tingkat kesempatan kerja, tingkat pendapatan, serta tingkat kepemilikan aset. Kemudian sisi sosial dapat dilihat dari tingkat kriminalisasi yang dialami, hubungan dengan sesama masyarakat, dan hubungan dengan pihak lain yang berkonflik.

\section{Hipotesis Penelitian}

Berdasarkan kerangka penelitian di atas, maka hipotesis penelitian yang diajukan oleh penulis dibagi menjadi dua yaitu:

\section{Hipotesis Pengaruh:}

1. Diduga konflik agraria dapat menyebabkan kejadian tersingkirnya masyarakat dari lahan mereka

2. Diduga tersingkirnya masyarakat dapat menyebabkan munculnya gerakan perlawanan petani

3. Diduga gerakan perlawanan petani mampu untuk menciptakan sebuah situasi untuk mendapatkan jaminan kontrol atas tanah

\section{Hipotesis Uji:}

1. Diduga semakin tinggi tingkat keberhasilan gerakan perlawanan petani maka akan semakin tinggi tingkat kesejahteraan ekonomi masyarakat

2. Diduga semakin tinggi tingkat keberhasilan gerakan perlawanan petani maka akan semakin tinggi tingkat kesejahteraan sosial masyarakat

\section{PENDEKATAN LAPANGAN}

\section{Lokasi dan Waktu Penelitian}

Penelitian dilakukan di Desa Sukamulya, Kecamatan Rumpin, Kabupaten Bogor. Pemilihan lokasi dilakukan secara purposive karena beberapa pertimbangan, diantaranya ialah:

1. Di Desa Sukamulya ini telah terjadi konflik antara masyarakat dengan pihak Lanud ATS sejak tahun 2007 dan belum selesai sampai saat ini.

2. Ada gerakan perlawanan berupa sebuah organisasi masyarakat bernama Paguyuban Petani yang sudah melakukan berbagai aksi dan kegiatan dalam upaya melawan Lanud ATS.

Kegiatan penelitian ini dilaksanakan mulai bulan Juni 2013 sampai dengan Januari 2014 yang meliputi penyusunan proposal penelitian, kolokium penyampaian proposal penelitian, perbaikan proposal penelitian, pengambilan data di lapangan, pengolahan dan analisis data, penulisan draft skripsi, uji petik, sidang skripsi, dan perbaikan laporan skripsi.

\section{Teknik Pemilihan Responden, Informan, serta Pengumpulan Data}

Sumber data pada penelitian ini menggunakan informasi yang berasal dari responden dan informan. Responden dalam penelitian ini adalah 20 orang rumah tangga yang menjadi anggota aktif dari Paguyuban Petani. Pemilihan responden diambil dengan metode pengambilan sampel jenuh (cencus sampling). Rianse dan Abdi (2009) menyatakan bahwa pengambilan sampel jenis ini dicirikan oleh jumlah populasi yang kurang atau sama dengan 50 orang sehingga pengambilan seluruh populasi sebagai sampel penelitian. Orang-orang yang dijadikan sebagai informan dalam penelitian ini adalah aparatur desa, ketua Paguyuban Petani, tokoh masyarakat setempat, dan KontraS sebagai LSM yang membantu masyarakat dalam menangani kasus konflik lahan di Desa Sukamulya.

Teknik pengumpulan data yang digunakan ialah teknik triangulasi yang terdiri dari observasi partisipatif, wawancara mendalam, dan penelusuran dokumen. Data yang digunakan dalam penelitian ini terdiri dari data 
primer dan sekunder. Data primer didapatkan langsung di lapangan dengan cara observasi, kuesioner, serta wawancara mendalam yang dilakukan langsung kepada responden maupun informan. Data sekunder diperoleh baik dari dokumen-dokumen tertulis di kantor desa, kantor kecamatan, kantor Paguyuban Petani, dan kantor KontraS.

\section{Teknik Pengolahan dan Analisis Data}

Penelitian ini mempunyai dua jenis data yang akan diolah dan dianalisis, yaitu data kuantitatif dan data kualitatif. Data kuantitatif menggunakan aplikasi Microsoft Excell 2007 dan IBM SPSS Statistic 20. Pembuatan tabel frekuensi, grafik, serta tabel tabulasi silang untuk melihat data awal responden untuk masing-masing variabel secara tunggal menggunakan aplikasi Microsoft Excell 2007. Kemudian IBM SPSS Statistic 20 digunakan untuk membantu dalam uji statitistik yang akan menggunakan Rank Spearman. Uji korelasi Rank Spearman digunakan untuk mengetahui ada atau tidaknya hubungan antar dua variabel yang berskala ordinal. Rank Spearman digunakan untuk uji korelasi yang menghubungkan variabel gerakan perlawanan petani terhadap tingkat kesejahteraan ekonomi dan sosial masyarakat Desa Sukamulya. Taraf nyata yang digunakan dalam pengolahan data kuantitatif adalah 99 persen atau nilai $\alpha$ sebesar 1 persen.

Kemudian untuk melakukan interpretasi mengenai kekuatan hubungan antar dua variabel, digunakan pendapat dari Sarwono (2009) dengan menggunakan kriteria sebagai berikut:

$$
\begin{array}{lll}
\text { - } & 0 & : \text { Tidak ada korelasi antara dua variabel } \\
\text { - } & >0-0.25 & : \text { Korelasi sangat lemah } \\
\text { - } & >0.25-0.5 & : \text { Korelasi cukup kuat } \\
\text { - } & >0.5-0.75 & : \text { Korelasi kuat } \\
\text { - } & >0.75-0.99: \text { Korelasi sangat kuat } \\
\text { - } & 1 & \text { : Korelasi sempurna }
\end{array}
$$

Data kualitatif dianalisis melalui tiga tahap yaitu reduksi data, penyajian data, dan verifikasi. Pertama ialah proses reduksi data dimulai dari proses pemilihan, penyederhanaan, abstraksi, hingga transformasi data hasil wawancara mendalam, observasi, dan studi dokumen. Tujuan dari reduksi data ini ialah untuk mempertajam, menggolongkan, mengarahkan, dan membuang data yang tidak perlu. Kedua ialah penyajian data yang berupa menyusun segala informasi dan data yang diperoleh menjadi serangkaian kata-kata yang mudah dibaca ke dalam sebuah laporan. Verifikasi adalah langkah terakhir yang merupakan penarikan kesimpulan dari hasil yang telah diolah pada tahap reduksi.

\section{PROFIL DESA SUKAMULYA}

Wilayah Desa Sukamulya adalah salah satu desa dari 13 desa yang terangkum dalam wilayah Kecamatan Rumpin, Kabupaten Bogor. Desa ini terletak diantara Hou 280 FT Lintang Selatan 06022'141' dan 106027'102' Bujur Timur. Desa ini berbatasan langsung dengan Provinsi Banten di sebelah utara, Kecamatan Gunung Sindur di sebelah timur, Desa Tamansari di sebelah selatan, dan Desa Mekarsari di sebelah Barat. Kawasan desa merupakan kawasan dataran rendah dengan ketinggian antara $12-15$ mdpl (meter di atas permukaan laut). Luas wilayah dari desa ini ialah
1070 hektar, yang terdiri dari 13 kampung dengan 8 Rukun Warga (RW) dan 42 Rukun Tetangga (RT). Nama kampung di desa ini antara lain Kampung Parigi, Kampung Malahpar, Kampung Cibitung, Kampung Nordin, Kampung Cilangkap, Kampung Peusar, Kampung Rancagaru, Kampung Cikoleang, Kampung Legok Nyenang, Kampung Leuwiranji, Kampung Ciputih, Kampung Medang, dan Kampung Nawing.

Hasil sensus penduduk tahun 2010 menyatakan bahwa penduduk Desa Sukamulya berjumlah 12876 jiwa. Jumlah rumah tangganya ialah sebanyak 2971 Rumah Tangga / KK dengan jumlah penduduk laki-laki sebanyak 6662 jiwa dan perempuan sebanyak 6214 jiwa. Jika dilihat dari tingkat pendidikan penduduk, tingkat Sekolah Dasar (SD) menempati jumlah paling banyak yaitu sebanyak 2578 dari 8554 jiwa.

Pada tahun 2010, terdapat 850 orang yang belum bekerja. Jumlah tersebut terdiri dari 550 orang laki-laki dan 300 orang perempuan. Hal ini disebabkan karena keterbatasan lapangan pekerjaan dan jumlah pencari kerja yang cukup banyak. Sepanjang jalan utama Desa Sukamulya, terdapat banyak sekali tempat penjualan pasir maupun bebatuan. Selain itu, juga terdapat warung-warung kecil yang biasanya berdiri di samping tempat penjualan pasir dan bebatuan.

\section{JEJAK KELAM KONFLIK AGRARIA DESA SUKAMULYA}

\section{Penjajahan Belanda}

Awal mulanya terdapat 4 kelurahan yaitu Kelurahan Malahpar, Cikoleang, Peusar, dan Leuwiranji. Pada saat itu, Belanda masih menjajah Indonesia termasuk di wilayah Kabupaten Bogor ini. Para tuan tanah menggunakan kekuasaan penjajah Belanda untuk merampas tanah rakyat dengan berbagai cara. Semakin lama semakin luas tanah tuan tanah, yang kemudian ditanami dengan tanaman pohon karet. Hal inilah yang menjadi asal mula perkebunan karet PT. Cikoleang. Pada saat itu, tenaga kerja yang dipakai ialah penduduk sekitar yang dibayar dengan menggunakan 0.5 liter beras setiap setengah harinya. Apabila terdapat tenaga kerja yang tidak bekerja, maka keesokan harinya tenaga kerja tersebut harus bekerja sehari penuh dengan bayaran setengah liter beras juga.

\section{Kerja Paksa dan Kedatangan Hasbullah (1943-1944)}

Pada awal tahun 1943, tentara Jepang membuat lapangan terbang Nordin di atas tanah warga. Warga tersebut berjumlah 19 orang pemilik penggarap yang luas tanahnya mencapai \pm 7 hektar dari sebelah barat dari perkebunan karet dan \pm 11 hektar dari sebelah timur. Panjang landasan tersebut ialah 1800 meter dan lebar 100 meter. Tanah warga yang digunakan sebagai lapangan oleh tentara Jepang dibayar dengan menggunakan check yang harus dicairkan di kantor pos pusat Gambir Betawi (Jakarta). Setelah sampai di kantor pos pusat, ternyata check itu tidak berlaku.

Adapun pembuatan landasan kapal menggunakan tenaga penduduk sekitar yang dikerjapaksakan sebagai Romusha dengan bayaran tidak menentu. Pada tahun 1944, pembuatan lapangan terbang sudah hampir selesai. Kemudian tentara Jepang membawa seseorang yang berasal dari Rangkasbitung yang bernama Hasbullah. 
Hasbullah yang bisa membaca dan menulis, dijadikan sebagai mandor oleh tentara Jepang dan perilakunya sama dengan tentara Jepang. Hasbullah datang pada waktu membuat perlindungan kapal di kampung Malahpar.

\section{Peristiwa Pulang Kampung (1945-1948)}

Tentara Jepang bertekuk lutut kepada Sekutu. Lapangan terbang Nordin pun diserang oleh tentara NICA. Tentara Jepang ditangkap oleh NICA dan jika ada tentara Jepang yang lari ke kampung maka akan dibantai oleh warga. Hasbullah pun saat itu dicari-cari oleh warga namun entah dimana ia bersembunyi. Pada tanggal 17 Agustus 1945, proklamasi kemerdekaan bergema di Nusantara. Banyak warga desa yang masuk Tentara Keamanan Rakyat (TKR) kemudian menjadi Tentara Nasional Indonesia (TNI). Semenjak Indonesia merdeka, masyarakat yang lainnya kembali ke desa-desa untuk mengambil kembali tanah mereka yang direbut paksa oleh Jepang. Mereka membuka kembali kampung halaman serta ladang yang sudah menjadi hutan belukar dan tempat babi hutan bersarang.

\section{Hasbullah dan TNI AU (1948-1959)}

Kemudian pada tahun 1955/1956, Letnan Tjahyono datang bersama Hasbullah yang mengklaim tanah masyarakat di kampung Cikoleang sebelah barat Kampung Rancagaru/ Rancamoyan, Kampung Peusar, Kampung Cilangkap, kampung Nordin, kampung Parigi sebelah timur, Kampung Malahpar, dan Kampung Cibitung. Mereka menyatakan bahwa tanah-tanah tersebut di atas diklaim menjadi milik TNI Angkatan Udara.

\section{Kesepakatan Awal (1960-1990)}

Pada tahun 1960 diadakan musyawarah oleh Bupati Bogor, Badan Pertanahan Nasional (BPN), DPRD Kabupaten Bogor, Kodim, Polres, Korem, TNI AU, dan Lanud Atang Sanjaya (selanjutnya disebut Lanud ATS) antara Kol. Soetopo dengan tokoh masyarakat serta masyarakat lainnya yang menghasilkan keputusan yaitu :

1. Komandan Landasan Udara Atang Sanjaya Kolonel Soetopo mengatakan bahwa tanah yang menjadi hak TNI AU hanya lapangan terbang Nordin yang panjangnya 1800 meter dan lebar 100 meter, serta minta tanah eks perkebunan karet PT. Cikoleang selebar 50 meter sepanjang landasan lapangan terbang Nordin. Berarti total luasnya $27 \mathrm{Ha}$

2. Luar dari pada itu silahkan dimiliki oleh masyarakat Kemudian pada tahun 1976 tanah tersebut dirinci oleh Badan Pertanahan Nasional (BPN) dari Bandung Jawa Barat untuk dibuatkan Kitir atau Girik. Apabila tanah diperjualbelikan maka akan keluarlah kitir atau girik tanah. Bagi masyarakat yang mempunyai biaya, bisa membuat surat tanah menjadi hak milik (sertifikat).

\section{Pengklaiman Tanah dan Perlawanan H. Amsari (1991-} 1998)

Pada tahun 1991 ketika Desa Sukamulya dijabat oleh H. Amsari dengan gencar Lanud ATS mengklaim tanah seluas 1000 Ha. Pada hari Kamis tanggal 2 Mei 1991 di Pendopo Pemda Kabupaten Bogor diadakan pembahasan masalah tanah TNI Angkatan. Wakil Komandan Lanud ATS Kolonel Tatang mengatakan bahwa TNI AU memiliki tanah seluas
2000 sampai dengan 4000 Ha serta tidak akan mengusir yang berarti bahwa tanah yang ditempati dipersilahkan saja. Itulah kesaksian dari Hasbullah. Kemudian Kolonel Tatang memperkenalkan Hasbullah. Hasbullah pun berbicara yang intinya adalah sebagai berikut :

1. Kalau tidak kuat iman, Hasbullah telah pergi dari Rumpin karena di kejar akan dibunuh oleh orang Rumpin

2. Hasbullah berada di Rumpin sudah 47 tahun

3. Uang ganti rugi dari Jepang sebanyak 49 peti sudah dibagikan kepada sebanyak 25000 masyarakat yang paling banyak terdapat di Desa Sukamulya hingga mencapai 15000 orang

4. Amanat tentara Jepang kepada Hasbullah, lalu Hasbullah menyerahkan kepada Angkatan Udara

5. Di Desa Sukamulya tidak akan terjadi peristiwa seperti ini seandainya lurahnya bekerjasama dengan Hasbullah

Kemudian Kepala Desa H. Amsari dipersilahkan bicara oleh Bupati Bogor, H. Amsari yang mengatakan bahwa :

Pertama : Menjelaskan dan menunjukan tanda bukti kepemilikan tanah masyarakat berupa kitir atau girik dan surat hak milik (sertifikat) dari Badan Pertanahan Nasional (BPN) Bogor. Dijelaskan juga hasil musyawarah pada tahun 1960

Kedua : H. Amsari (kepala desa waktu itu) membahas kesaksian Hasbullah dari TNI Angkatan Udara yaitu :

1. Andainya Hasbullah pada tahun 1945 ketangkap bersama tentara Jepang dia pasti sekarang tidak akan hadir disini. Hasbullah merupakan pengikut tentara Jepang yang juga kejam seperti Jepang

2. Ganti rugi yang dikatakan Hasbullah itu bohong, tidak ada penggantian yang ada hanya check kosong kepada 19 orang pemilik tanah yang dipakai landasan

3. Amanat tentara Jepang kepada Hasbullah itu menandakan Hasbullah pengikut setia tentara Jepang. Lalu Hasbullah menyerahkan kepada TNI Angkatan Udara itu suatu hal yang mustahil tidak ada kamusnya

4. Hasbullah berada di Rumpin sudah 47 tahun itu benar, karena Hasbullah datangnya ke Desa Sukamulya bersamaan dengan tentara Jepang pada tahun 1944

5. Hasbullah mengatakan di Desa Sukamulya tidak akan terjadi seperti ini kalau saja lurahnya bekerjasama dengan Hasbullah.

Maka jelaslah tanah yang di klaim oleh TNI Angkatan Udara hanya rekayasa Hasbullah. Jika ditelisik pada Surat Kepala Staf Angkatan Perang Nomor 023/KSAP/1950 tanggal 25 Mei 1950, yang berbunyi :'Lapangan terbang serta bangunan-bangunan yang termasuk lapang dan alat-alat yang berada di lapangan dan sungguh-sungguh diperlukan untuk memelihara lapangan-lapangan tersebut menjadi milik Angkatan Udara Republik Indonesia". Jelaslah kalimat diatas dimaksudkan hanya lapangan terbang Nordin yang luasnya $18 \mathrm{Ha}$.

\section{Meletusnya "Perang” di Desa Sukamulya (2003-2007)}

Turun Surat Keputusan Bupati Bogor Nomor 591/194/ KPTS/HUK/2003 pada tanggal 12 Juni 2003 tentang 
penetapan pembagian/pengalokasian atas tanah Eks HGU PT. Cikoleang seluas $90 \mathrm{Ha}$ dan seterusnya. Kemudian pada tanggal 21 September 2005, Pangkalan TNI AU Lanud ATS mengeluarkan surat No: B/480/IX/2005 yang ditandatangani oleh Marsekal Pertama Ignatius Basuki tentang Permohonan Pencegahan Penerbitan dan Pemblokiran Sertifikat di Atas Tanah TNI AU. Surat ditujukan kepada Kepala Kantor Pertanahan Kabupaten Bogor. Pada tanggal 8 September 2006, TNI AU Lanud ATS mendatangi tanah lokasi Pemda, desa, dan kavling masyarakat untuk merusak patok batas tanah. Kemudian TNI AU Lanud ATS memasang plang yang bertuliskan ini tanah milik TNI AU berdasarkan SK. KSAP Nomor 023/ KSAP/1950.

Pada bulan Oktober 2006, Ketua RT 01/05 kampung Cibitung yaitu H. Amir terus menerus didatangi oleh Kolonel Dery yang bermaksud untuk membuat Water Training di atas tanah sawah blok Cisauk persil 20 seluas 10 Ha dengan harga Rp 7000 permeter perseginya. Tetapi pemilik tanah sawah tidak mau menjual dan warga juga keberatan apabila akan digali dengan alasan apapun, sedangkan alat-alat besar seperti beko dan alat-alat lainnya sudah ada dilokasi tanah aset desa Sukamulya. Kesimpulan rapat antara mereka menyatakan supaya alat berat beko dan alat-alat lainnya supaya diangkat dari lokasi tersebut pada saat itu juga, selang satu hari dikeluarkanlah alat beko dan lainnya dari lokasi itu.

Tetapi tanggal 7 November 2006, Lanud ATS datang kembali dengan membawa beko dan beberapa alat untuk menggali pasir serta alat-alat bangunan dengan dikawal oleh tentara TNI AU membawa senjata lengkap laras panjang ditangan. Hari Sabtu tanggal 25 November 2006 sebanyak \pm 250 orang datang untuk berdemo agar Lanud ATS hengkang dari lokasi. Pada hari Rabu tanggal 14 November 2006 warga melakukan aksi lagi berupa penutupan (pemblokiran) jalan yang menuju lokasi Lanud ATS dengan patok dan besi cor. Kemudian TNI AU datang dengan senjata laras panjang membuka patok jalan. Hari Selasa tanggal 5 Desember 2006, warga melakukan aksi unjuk rasa untuk menyalurkan aspirasinya di gedung DPRD Bogor \pm 300 orang meminta kepada Bupati dan DPRD menghentikan pembangunan proyek Water Training oleh Lanud ATS yang menyerobot dan merampas tanah sawah milik warga yang merupakan tanah produktif.

Hari Minggu tanggal 10 Desember 2006 warga melakukan aksi unjuk rasa kembali dan berorasi dijalan CisaukCicangkal serta beramai-ramai mendatangi lokasi sawah yang digali oleh TNI AU yang sudah mencapai luasan $2 \mathrm{Ha}$ sedalam 2 meter. Hari Kamis tanggal 14 Desember 2006, perwakilan warga mendatangi Badan Pertanahan Nasional (BPN) Pusat yang berjanji akan datang ke BPN Bogor dan meninjau lokasi antara 3-8 hari setelah pertemuan ini dilaksanakan.

"Bahasanya water training tapi yang ada galian pasir. Jadi akhirnya terjadi konflik. Wajar kalau masyarakat bertahan atas tanah miliknya, atas lahan pertaniannya." - JLN, aparat pemerintahan desa.

"Sebetulnya ini yang menjadi pertanyaan besar, mau jadi proyek water training atau proyek galian pasir? Sebenarnya banyak lahan lain yang lebih cocok, tetapi justru di atas lahan yang masih produktif. Ketika lahan produktif digaruk atau dibabat, enggak bisa insentif lagi kan, dan berdampak kepada sistem pengairan. Kita lihat misalnya lahan menjadi kering dan sawah yang tidak mendapatkan air akibat dari pengerukan." SKO, aktivis KontraS

Hari Sabtu tanggal 23 Desember warga melakukan aksi unjuk rasa kembali menutup jalan yang menuju lokasi dengan menggunakan sirtu (batu pasir) dan langsung berorasi menuju Balai Desa Sukamulya. Kemudian menuju lokasi tanah sawahnya yang digali oleh Lanud ATS. Hari Minggu tanggal 24 Desember 2006, Lanud ATS menurunkan beko ke sawah warga dengan tujuan untuk membuat galian baru dengan dikawal oleh TNI AU bersenjatakan laras panjang yang ditodongkan ke depan. Spontan ibu-ibu warga masyarakat turun untuk menghalau beko yang sudah turun kesawah, menangis, dan memburu beko yang sedang menggali tanah sawah.

"Ibu paling depan, ada di koran, di tipi, dimanamana. Bahkan ibu nenteng-nenteng batu. Nih, batu buat ngelemparin dia. Supir biku itu. Kesel banget kalo liat biku (beko), ngeong ngeong gunjreng. Udah panas, udah jengkel nih hati ibu." SDH, 40 tahun

Pada tanggal 22 Januari 2007, terjadi kekerasan terhadap warga yang melakukan aksi untuk menolak pembangunan water training. Kejadian ini terjadi sekitar pukul dua siang sampai dengan empat sore. Masyarakat hanya menggunakan senjata tradisional seperti bambu runcing atau batubatuan untuk melawan TNI AU. Tetapi TNI AU justru menggunakan senjata laras panjang untuk melawan warga. Tak terelakkan, "perang" di Desa Sukamulya pun terjadi. Ada beberapa warga yang melempar batu dan mengenai salah seorang anggota TNI AU tersebut. Akhirnya, TNI AU yang menggunakan senjata laras panjang sempat melepaskan beberapa tembakan. Dari beberapa tembakan yang dilepaskan, salah satunya mengenai seorang warga berinisial ACP. ACP mendapatkan luka tembakan di bagian belakang telinga sebelah kiri. Selain itu, beberapa orang lainnya termasuk anggota TNI AU mengalami luka dan harus dilarikan ke rumah sakit. Selain itu beberapa orang pingsan dan banyak korban lainnya. Termasuk salah satu aktivis yang sedang tinggal di sana untuk melakukan pendampingan, saat itu menjadi sasaran kekerasan dari TNI AU.

Setelah kejadian perang yang meletus pada tanggal 22 Januari tersebut, selama tiga hari berturut-turut TNI AU melakukan sweeping atau penyisiran ke rumah-rumah warga terutama di Kampung Cibitung dan sebagian Kampung Malahpar. Sehingga banyak warga terutama lakilaki yang bersembunyi atau melarikan diri ke luar desa. TNI AU melakukan penyisiran dengan mendatangi rumah sampai masuk ke dalam dan mengecek setiap tempat. Jika ada yang terlihat mencurigakan maka akan langsung dibawa oleh mereka.

"Rumah saya terutama, diacak-acak. Pakaian juga. Pintu juga dijebolin sama dia (TNI)" SDD, 48 tahun.

Ada sekitar 20 kepala keluarga yang terpaksa pindah dari rumah mereka. Tanah mereka dibeli secara paksa oleh Lanud ATS. Ada unsur pemaksaan, intimidasi, dan ancaman 
saat warga dipaksa untuk menerima uang kerohiman. Uang kerohiman adalah istilah untuk uang yang diberikan kepada warga sebagai ganti atas tanah mereka yang diambil oleh Lanud ATS. Berdasarkan penuturan salah seorang responden, warga yang dipaksa angkat kaki dari tanah mereka banyak yang tidak jelas keberadaannya saat ini. Satu hal yang pasti adalah mereka menjadi lebih miskin karena uang ganti yang tak sepadan.

\section{KISAH HEROIK GERAKAN PAGUYUBAN PETANI VERSUS NEGARA}

\section{Cikal Bakal Pembentukan Paguyuban Petani}

Masyarakat Desa Sukamulya merasakan adanya suatu kebutuhan yang cukup mendesak, dimana mereka merasa tidak mempunyai tempat untuk bernaung, berlindung, dan menyatu. Sekitar bulan September atau Oktober 2007, beberapa warga pergi bersama-sama ke KontraS di Jakarta. Di sekretariat itu, ada perwakilan dari sembilan kampung di Desa Sukamulya. Kampung-kampung tersebut antara lain Cikoleang, Parigi, Cilangkap, Cibitung, Malahpar, Peusar, Legokjenang, Nordin, dan Rancagaru. Setelah bermusyawarah, mereka memutuskan untuk membentuk sebuah perkumpulan yang dinamakan Paguyuban Petani. Paguyuban berasal dari kata dasar guyub yang berarti rukun, sedangkan kata petani digunakan sebagai identitas leluhur mereka yang berprofesi sebagai petani. Paguyuban Petani dibentuk juga untuk mengembalikan tanah yang diklaim sehingga menjadi milik masyarakat sepenuhnya. Paguyuban Petani terdiri atas tiga unsur yaitu ketua, simpul, dan anggota. Simpul adalah setiap kader yang ditunjuk dari masing-masing kampung sedangkan anggota ialah keseluruhan masyarakat Desa Sukamulya.

\section{Kepemimpinan dalam Paguyuban Petani}

Sesuai dengan kesepakatan bersama, Bapak SNI ditunjuk sebagai Ketua Paguyuban Petani. Bapak SNI dinilai mampu untuk memimpin Paguyuban Petani karena telah mempunyai beberapa pengalaman organisasi dan politik dibanding dengan beberapa warga lainnya. Hal yang pertama dilakukan oleh masyarakat ialah menunjukkan bahwa Paguyuban Petani ini ada dan diakui keberadaannya oleh pihak lain. Oleh karena itu, mereka membuat sebuah acara dalam bentuk Tabligh Akbar. Bapak SNI menggunakan jaringan yang dimilikinya dahulu sehingga ia mampu untuk mengundang seseorang dari Komisi II DPR yaitu Bapak SMM. Acara ini menghabiskan dana sekitar 65 juta rupiah dan ditanggung sepenuhnya oleh Bapak SNI.

Setelah itu langsung saja nama Paguyuban Petani meluas termasuk di kalangan DPR RI. Lalu ada beberapa orang termasuk Ketua Komisi I, Ketua Komisi II maupun beberapa fraksi partai yang memberikan respon terhadap Paguyuban Petani. Sejak saat itu, Paguyuban Petani mendapatkan skala prioritas di kalangan DPR RI bahkan sudah dilaksanakan beberapa kali rapat dengar pendapat di sana. Isu Paguyuban Petani telah menjadi sebuah isu nasional, dimana mendapatkan skala prioritas untuk diperbincangkan dalam rapat dengar pendapat DPR RI. Hal ini tidak terlepas dari kemampuan pemimpinnya yaitu Bapak SNI. Jaringan dan strategi yang dimiliki oleh Bapak SNI dalam memperkenalkan Paguyuban Petanilah yang mampu membuatnya dikenal oleh orang banyak.
Sebagian besar responden menganggap bahwa kepemimpinan yang dibawakan oleh Bapak SNI tergolong baik. Hal tersebut ditunjukkan pada gambar bahwa sebanyak 27 responden memberikan jawaban baik, 22 responden memberikan jawaban sangat baik, dan hanya 1 responden yang memberikan jawaban biasa saja. SNI dianggap mampu untuk mengajak serta masyarakat untuk berpartisipasi dalam kegiatan Paguyuban Petani.
"Pak SNI itu bisa paham keinginan dari simpul- simpulnya. Mudah juga untuk ditemui serta semangat. Asal kita masukin aspirasi, ia langsung bersemangat. Ia mempunyai kekhasan tersendiri dibandingkan dengan lainnya." SNN, 58 tahun

Ada satu hal yang membedakan Bapak SNI dengan beberapa orang lainnya. Menurut responden, Bapak SNI memiliki kemampuan melobi yang baik dan juga jaringanjaringan politik yang cukup kuat dari pengalamannya. Selain itu, beberapa responden juga menyatakan bahwa Bapak SNI termasuk orang yang sering memberikan masukan-masukan yang bijak dan baik dalam Paguyuban Petani, serta dermawan dan baik hati. Seringkali beberapa kegiatan Paguyuban Petani yang memerlukan dana ditanggung sendiri oleh dirinya. Selain mudah ditemui dan dimintai bantuan apabila ada kesulitan, Bapak SNI juga dekat secara emosional dengan para anggota simpul maupun masyarakat Desa Sukamulya.

\section{Kolektifitas Simpul: Nyawa Paguyuban Petani}

Persoalan turun langsung ke masyarakat Desa Sukamulya ditangani langsung oleh para simpul. Simpul adalah sebutan bagi para perwakilan dari kampung-kampung yang berada di Desa Sukamulya. Pada saat pembentukan Paguyuban Petani di sekretariat KontraS, para simpul juga ikut dibentuk. Mereka ialah para perwakilan 9 kampung yang mengikuti musyawarah tersebut. Tugas utama dari para simpul ini ialah mengkoordinasikan segala hal. Termasuk didalamnya menyampaikan hasil rapat maupun segala aktivitas paguyuban Petani, memberikan pemahaman serta penjelasan kepada masyarakat, serta menggalang tenaga maupun dana dari masyarakat.

Sebagian besar responden menganggap bahwa kolektifitas yang ditunjukkan oleh para simpul tergolong kuat. Hal tersebut ditunjukkan dari gambar tersebut bahwa dari 50 responden sebanyak 36 responden memberikan jawaban kuat, 13 responden memberikan jawaban sangat kuat, dan hanya 1 responden yang memberikan jawaban biasa saja. Masyarakat termasuk simpul-simpul sendiri merasakan bahwa rasa kebersamaan sangat kuat.
"Ada apapun kita selalu musyawarah, selalu kumpul apa yang mau kita lakukan selanjutnya. Alhamdulillah, tetapi kita jagalah (hubungan) sampai sekarang. Meskipun jauh, komunikasi tetap lancarlah.” AZN, 44 tahun.
"Iya, saling membantu kalau ada apa-apa. Kalau ada peristiwa apa-apa waktu itu juga dia yang ngurusin (simpul). Banyak tempat kita minta tolong aja ah, guyub gitu dia mah." MMM, 35 tahun.

\section{Perjuangan Paguyuban Petani: Diskusi Sampai Aksi}

Sejak dibentuk pada akhir tahun 2007 sudah tak terhitung 
lagi banyaknya bentuk perjuangan yang dilakukan oleh Paguyuban Petani. Diawali dengan rapat organisasi, rapat dengan pihak-pihak lain, melobi berbagai unsur masyarakat maupun negara untuk mendukung mereka, serta aksiaksi demonstrasi. Aksi besar-besaran yang dilakukan oleh Paguyuban Petani sudah berjalan sebanyak 4 kali ke DPR. Tetapi yang paling menjadi sorotan ialah aksi pada tanggal 11 Mei 2011 dengan massa sekitar 6000 orang. Komunikasi dengan Lanud ATS mulai dilakukan sejak aksi besar 11 Mei 2011, karena ada dorongan dari masyarakat, Lanud ATS akhirnya mulai membuka diri untuk duduk bersama.

Puncak dari perjuangan Paguyuban Petani terletak saat pembentukan tim verifikasi yang terdiri atas beberapa unsur. Unsur-unsur tersebut antara lain BPN Kabupaten Bogor, TNI AU Cq. Lanud ATS, Kecamatan Rumpin, Polsek Rumpin, Koramil Rumpin, aparat Desa Sukamulya, serta tokoh masyarakat Desa Sukamulya. Kemudian tim verifikasi melakukan penelusuran batas-batas tanah di Desa Sukamulya dan mendapatkan hasil terhadap GS 557/1977 atas nama LAPAN seluas 449,2490 Ha yang terdiri dari 2 status tanah sebagai berikut:

1. Tanah Negara bekas Eigendom Verponding No.67 (sisa), No.68 (sisa), dan No.113 (sisa) atas nama Cuultur Mutscheping Tjikoleang yang terkena Undang-undang No.1 tahun 1958 tentang penghapusan tanah-tanah partikelir, dengan rincian:

a. Yang telah terdaftar haknya:

- Sertifikat Hak Pakai No.3/Skm, seluas 10.912 Ha a.n. Lapan

- Sertifikat Hak Pakai No.4/Skm, seluas 39.0800 Ha a.n. Lapan

- Sertifikat Hak Pakai No.5/Skm, seluas 16 Ha a.n. Pemkab Bogor

b. Yang belum terdaftar haknya:

- Seluas 36.6 Ha berdasarkan SK Menteri Agraria No.SK. $968 / \mathrm{Ka}$ pada $28-12-1960$, hasil pengukuran seluas $240.555 \mathrm{~m} 2$

- Seluas 173.788 m2 (MAKO BRAVO PASKHAS TNI AU)

- Seluas $119.550 \mathrm{~m} 2$ (merupakan sebagian dari Peta Bidang Tanah No.01/2003 atas nama LAPAN)

- Seluas $25.670 \mathrm{~m} 2$ (merupakan sebagian dari Hak pakai No.4/Sukamulya atas nama LAPAN)

- Seluas $190.000 \mathrm{~m} 2$ (merupakan wilayah Water Training TNI AU) berdasarkan hasil pembebasan.

2. Tanah adat yang telah terdaftar haknya seluas 28.5758 Ha An. Lim Hendra Halim dkk dan tanah adat lain diketahui luasannya karena belum didaftarkan ke BPN oleh masyarakat

3. Bahwa GS.557/1977 seluas 449.2490 Ha dengan Nomor Register IKN 50503007 ternyata didalamya sudah penuh dengan bangunan-bangunan pemukiman masyarakat dan lahan pertanian masyarakat

4. Bahwa terhadap Register IKN 50503008 seluas 550 Ha yang diperkirakan berada di Desa Kertajaya, Desa
Mekarsari, dan Desa Tamansari belum pernah diadakan pengukuran oleh BPN dan akan diadakan verifikasi lebih lanjut.

Laporan berita acara hasil verifikasi ini telah disampaikan ke beberapa pihak diantaranya MenKeu, MenHan, BPN Pusat, BPN Jawa Barat, BPN Kabupaten Bogor, Pemerintahan Daerah Kabupaten Bogor, DPRD Kabupaten Bogor, Kantor Kecamatan Rumpin, dan Kantor Desa Sukamulya. Tetapi hal yang paling disayangkan ialah belum adanya respon yang jelas dan pasti dari pihak-pihak tersebut. Sehingga sampai saat ini, masyarakat hanya memiliki bukti berbentuk girik tanah dan belum diajukan menjadi sertifikat tanah. Pembuatan sertifikat tanah belum bisa dilakukan oleh BPN selama pihak Lanud ATS belum mencabut klaim atas lahan yang mereka ajukan di Desa Sukamulya ini.

Perjuangan yang telah dilakukan oleh masyarakat tergolong ke dalam perlawanan masif yang dibuktikan dengan konsistensi perjuangan yang terus dilakukan oleh masyarakat Desa Sukamulya terhadap Lanud ATS. Semakin lama perlawanan tersebut semakin besar dan melibatkan berbagai unsur masyarakat maupun negara didalamnya. Isu konflik di desa ini juga sudah memasuki ranah nasional dengan dilakukannya rapat dengar pendapat di DPR RI. Jadi, dapat dikatakan bahwa konflik yang terjadi di Desa Sukamulya termasuk ke dalam konflik terbuka. Hal ini terlihat dari pihak masyarakat maupun Lanud ATS yang sama-sama menyatakan bahwa mereka sedang berkonflik dan sudah terjadi kontak fisik diantara keduanya. Setelah ada Paguyuban Petani, strategi masyarakat mulai bergeser dari konfrontatif ke kolaboratif. Perlawanan secara radikal tidak lagi dilakukan, tetapi justru memanfaatkan celahcelah ruang politik yang tersedia. Selain itu, tersedianya akses untuk mendapatkan bantuan dari pihak lain juga semakin terbuka lebar.

Intensitas kegiatan yang dilakukan oleh para simpul tergolong sering. Hal tersebut ditunjukkan pada gambar tersebut bahwa dari 50 responden sebanyak 42 responden memberikan jawaban sering dan 8 responden memberikan jawaban sangat sering. Hampir seluruh responden merasakan bahwa kegiatan Paguyuban Petani sering dilakukan, baik rapat internal maupun aksi-aksi yang dilakukan. Terlebih, sesaat setelah perang di Desa Sukamulya terjadi maupun awal mula pembentukan Paguyuban Petani. Saat melakukan wawancara mendalam, sebagian besar responden menyatakan bahwa mereka sudah tak mampu mengingat jumlah kegiatan Paguyuban Petani secara rinci. Tetapi pada saat ini, kegiatan yang dilakukan Paguyuban Petani memang tidak terlalu sering seperti pada tahun 2008-2012. Hal ini disebabkan, sekarang Paguyuban Petani hanya perlu untuk mendesak pihak Lanud ATS agar mencabut klaim mereka dan melaksanakan hasil tim verifikasi secara keseluruhan.

\section{Bantuan Penggerak Paguyuban Petani}

Paguyuban Petani berawal dari pembicaraan yang dilakukan di sekretariat KontraS. Hal ini berarti Paguyuban Petani mendapat bantuan dari pihak di luar masyarakat. Hasil wawancara mendalam menunjukkan ada beberapa pihak luar yang konsisten membantu masyarakat Desa Sukamulya sampai saat ini antara lain KontraS, Aliansi Gerakan Reforma Agraria (AGRA), Wahana Lingkungan Hidup Indonesia (Walhi), dan Lembaga Bantuan Hukum 


\section{di Jakarta (LBH).}

"Tahun 2006 akhir, kita (KontraS) kedatangan masyarakat untuk meminta bantuan Kontras atas permasalahan yang terjadi di sana (Desa Sukamulya) terkait konflik tersebut. Nah, dua atau tiga kali kemudian bahan-bahan itu kita pelajari. Kita bersama rekan-rekan jaringan yang lain melakukan komunikasi yang agak dalam, terkait dengan permasalahan tersebut termasuk pemetaan, wawancara-wawancara, termasuk juga menentukan langkah apa yang akan kita lakukan., SKO, aktivis KontraS

Ada banyak bantuan yang diberikan oleh pihak-pihak luar ini, misalnya seperti bantuan moril berupa dukungan dan dorongan, pendampingan, penyuluhan, serta sedikit bantuan materiil. Dukungan dan dorongan memang tidak bisa diukur secara pasti karena hanya bisa dirasakan, tetapi masyarakat memang merasakan hal tersebut berdasarkan hasil wawancara mendalam yang dilakukan. Pendampingan dan penyuluhan sangat membantu masyarakat karena mereka menjadi lebih tahu mengenai kasus mereka sendiri dan membantu dalam menentukan langkah selajutnya yang akan diambil oleh masyarakat. Tak jarang pula disediakan sedikit bantuan materiil berupa mobil sewaan, ambulan, maupun konsumsi saat masyarakat Desa Sukamulya melakukan aksi.

Sebagian besar responden menganggap bahwa bantuan yang diberikan oleh pihak luar kepada Paguyuban petani hampir seimbang antara sering dan sangat sering. Hal tersebut ditunjukkan pada gambar tersebut bahwa dari 50 responden sebanyak 26 responden memberikan jawaban sering dan 24 responden memberikan jawaban sangat sering. Bantuan dari pihak luar ini memberikan kesempatan yang luas bagi masyarakat terutama Paguyuban Petani untuk belajar. Mereka dapat memahami kondisi yang mereka hadapi serta mendapatkan kesempatan untuk meningkatkan kapasitas mereka, sehingga dalam melakukan perjuangan, mereka tidak lagi diremehkan oleh pihak lawan. Kesempatan untuk berpolitik juga terbuka lebar dengan bantuan dari pihak luar. Masyarakat dapat melakukan aksi-aksi bahkan sampai terjadi audiensi maupun rapat dengar pendapat di berbagai instansi yang terkait.

\section{Penciptaan Situasi dan Keberhasilan Kontrol atas Tanah}

Jika dilihat secara keseluruhan, ternyata konflik yang terjadi hanya konflik vertikal saja di Desa Sukamulya. Konflik vertikal ini terjadi antara negara yang diwakili Lanud ATS dan masyarakat Desa Sukamulya. Konflik horizontal tidak terjadi di desa ini karena masyarakat tak berkonflik satu sama lain. Mereka justru bersatu dalam sebuah wadah yang berwujud organisasi bernama Paguyuban Petani. Pada awalnya masyarakat hanya bergerak secara radikal serta acak yang ditunjukkan pada saat "perang", maka Paguyuban Petani diciptakan sebagai wadah untuk menampung aspirasi maupun untuk bergerak secara lebih teratur dan terarah.

Ada 4 faktor yang menjadi tolak ukur tingkat keberhasilan gerakan Paguyuban Petani di Desa Sukamulya ini. Keempat faktor tersebut antara lain kepemimpinan, kolektifitas simpul, kegiatan Paguyuban Petani, dan bantuan dari pihak luar. Keempat faktor tersebut membuat Paguyuban Petani mampu mendapatkan posisi tawar (bargaining power) yang lebih tinggi dibandingkan sebelumnya. Hal ini membuat Lanud ATS tak mampu untuk kembali menekan masyarakat dan mengambil tanah mereka secara paksa. Paguyuban Petani dan masyarakat mampu untuk mempertahankan sisa tanah yang diklaim.

Selain itu, Paguyuban Petani juga mampu mengangkat isu konflik ke ranah nasional, mendapatkan perhatian dari pejabat atau instansi yang terkait. Sehingga muncul rapat dengar pendapat atau audiensi di berbagai tempat. Pembentukan tim verifikasi adalah puncak dari gerakan perlawanan Paguyuban Petani. Masyarakat yang diwakili oleh Paguyuban Petani dalam tim tersebut menjadi salah satu unsur yang turut menentukan batas penggunaan tanah di Desa Sukamulya. Seluruh hal inilah yang menunjukkan bahwa Paguyuban Petani cukup mampu untuk menciptakan situasi dimana mereka mendapatkan kontrol atas tanah serta berperan dalam penentuan penyelesaian kasus konflik tanah di Desa Sukamulya.

Tingkat keberhasilan gerakan Paguyuban Petani ditentukan secara keseluruhan oleh empat variabel yang telah disebutkan sebelumnya. Hasil kumulatif dari keseluruhan variabel untuk mengukur tingkat keberhasilan Paguyuban Petani dapat dilihat pada gambar berikut ini.

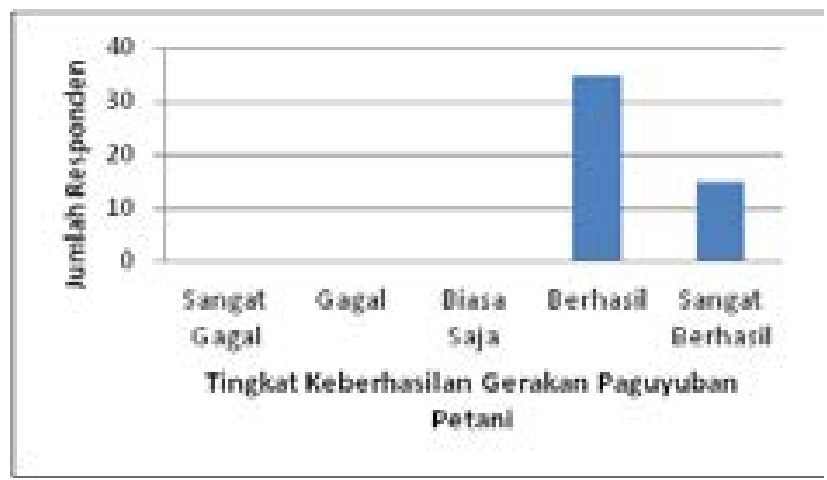

Gambar 1. Tingkat Keberhasilan Gerakan Paguyuban Petani Menurut Responden di Desa Sukamulya Tahun 2013

Gambar tersebut menunjukkan bahwa dari 50 responden sebanyak 35 responden memberikan jawaban berhasil dan 15 responden memberikan jawaban sangat berhasil. Responden menyatakan bahwa Paguyuban Petani sudah sangat membantu masyarakat. Mereka menilai bahwa jika tidak ada Paguyuban Petani maka saat ini mereka pasti sudah terusir dari tanah mereka di Desa Sukamulya. Paguyuban Petani benar-benar memperjuangkan hak tanah yang dimiliki masyarakat.

"Paguyuban ini bermanfaat bagi masyarakat, terutama dalam menangani kasus konflik ini." SGN, aparat pemerintahan desa.

Perlu ditekankan, meskipun Paguyuban Petani sudah termasuk dalam kategori berhasil dan mampu untuk mempertahankan serta mendapatkan kontrol atas sisa tanah yang terklaim, tetapi ada satu hal yang sampai saat ini belum tercapai. Hal tersebut adalah pembuatan sertifikat bagi seluruh tanah di Desa Sukamulya. Jadi, dapat dikatakan bahwa perjuangan Paguyuban Petani belum sepenuhnya terselesaikan. Paguyuban Petani masih tetap 
harus melakukan upaya desakan dan dorongan agar Lanud ATS mencabut klaim mereka sehingga masyarakat dapat membuat sertifikat tanah.

\section{DAMPAK GERAKAN PAGUYUBAN PETANI TERHADAP TINGKAT KESEJAHTERAAN MASYARAKAT}

\section{Perubahan Ekonomi dan Sosial Akibat Konflik Agraria di Desa Sukamulya}

Konflik agraria yang terjadi antara masyarakat Desa Sukamulya melawan negara yang diwakili Lanud ATS membawa perubahan-perubahan dalam kehidupan masyarakat. Pada awalnya, Lanud ATS mengklaim tanah seluas $1000 \mathrm{Ha}$ yang akhirnya berkurang menjadi 450 Ha di Desa Sukamulya. Hal ini berarti bahwa sebagian besar wilayah Desa Sukamulya terklaim oleh Lanud ATS. Padahal di tanah tersebut sudah ada pemukiman masyarakat setempat. Selain mengklaim, tiba-tba saja Lanud ATS membangun tempat latihan water training di atas lahan produktif masyarakat yang digunakan sebagai lahan garapan. Pendirian water training ini menyingkirkan sekitar 100 orang petani dan buruh tani dari lahan garapan mereka seluas 19 hektar. Saat ini, 100 orang tersebut banyak yang berubah menjadi buruh bangunan ataupun menganggur. Lanud ATS hanya mengganti lahan produktif tersebut dengan uang kerohiman Rp 5000 untuk setiap meternya. Lahan garapan ini ditanami dengan tanaman padi seluas 12 hektar dan palawija seluas 7 hektar. Jika dikonversi ke dalam satuan ton, maka setiap hektar per tahun akan menghasilkan padi dan palawija sekitar 2.5 ton. Masyarakat umumnya menggunakan hasil pertanian mereka untuk kebutuhan sehari-hari. Jika hasil tersebut dikonversi lagi ke dalam satuan rupiah, satu kilogram beras berharga Rp 6500 sehingga total uang yang bisa didapatkan untuk setiap hektarnya sebesar Rp 16250000 .

Selain itu, juga ada sekitar 20 kepala keluarga yang dipaksa pindah dari tempat tinggalnya karena tanah pemukiman mereka akan dibangun untuk perumahan TNI. Selain tempat tinggal, lahan perumahan TNI AU seluas 24 hektar itu juga awalnya terdiri atas tanah-tanah kosong. Penggantian yang diberikan juga berupa uang kerohiman sebesar Rp 5 000 setiap meternya. Pada tahun 2012, terjadi perluasan landasan udara TNI AU seluas 2 hektar. Pembelian tanah di sekitar landasan udara juga dilakukan dengan pemaksaan dan penggantian uang kerohiman sebesar Rp 50 000/m2.

Pada saat masyarakat melawan, justru mereka banyak mendapatkan tindak kekerasan bahkan sampai ada salah seorang masyarakat yang tertembak. Pelakuan yang diterima oleh masyarakat inilah yang mengubah kehidupan sosial mereka. Mereka menjadi ketakutan dan trauma akan keberadaan TNI AU. Keseluruhan hal ini tentu berpengaruh terhadap kehidupan masyarakat yang tersingkir dari tanahnya maupun yang terklaim, termasuk kesejahteraan mereka baik dari segi ekonomi maupun sosial. Kemudian muncul Paguyuban Petani sebagai bentuk perlawanan masyarakat untuk mengembalikan hak tanah dan kehidupan masyarakat seperti sebelum terjadinya konflik, dalam kata lain ialah mengembalikan kesejahteraan masyarakat.

\section{Dampak Paguyuban Petani terhadap Kesejahteraan Ekonomi Masyarakat}

Tingkatkesejahteraan ekonomimasyarakatDesa Sukamulya diukur dari tiga variabel yaitu tingkat kesempatan kerja, tingkat pendapatan, dan tingkat kepemilikan aset. Tingkat kesempatan kerja adalah persepsi anggota Paguyuban Petani terhadap terbukanya peluang masyarakat untuk bekerja baik untuk sektor pertanian maupun sektor nonpertanian. Tingkat pendapatan adalah persepsi ukuran besaran pendapatan yang didapat oleh anggota Paguyuban Petani baik untuk sektor pertanian maupun sektor nonpertanian. Tingkat kepemilikan aset adalah ukuran asetaset materiil yang dimiliki oleh anggota Paguyuban Petani baik sebelum dan sesudah munculnya Paguyuban Petani. Aset-aset yang diukur antara lain kepemilikan tanah, kondisi tempat tinggal, dan kepemilikan barang berharga. Pengukuran dilakukan untuk melihat perbedaan antara tingkat kesejahteraan ekonomi masyarakat sebelum dan sesudah munculnya Paguyuban Petani.

Tingkat kesempatan kerja sebelum dan sesudah munculnya Paguyuban Petani memiliki perubahan yang cukup baik. Responden menilai bahwa lebih mudah untuk mencari pekerjaan pada saat ada Paguyuban Petani. Hal yang perlu ditekankan ialah bukan disediakannya lapangan pekerjaan oleh Paguyuban Petani tetapi disediakannya akses untuk mencari dan mendapatkan pekerjaan ke luar desa. Responden merasa lebih aman dalam mencari pekerjaan maupun dalam bekerja karena adanya Paguyuban Petani yang melindungi mereka.

Tabel 1. Jumlah Responden berdasarkan Variabel Tingkat Kesejahteraan Ekonomi Sebelum dan Sesudah Munculnya Paguyuban Petani

\begin{tabular}{llcc}
\hline $\begin{array}{l}\text { Variabel } \\
\text { Tingkat Kes- } \\
\text { ejahteraan } \\
\text { Ekonomi }\end{array}$ & Skala & $\begin{array}{l}\text { Sebelum } \\
\text { Pa- } \\
\text { guyuban } \\
\text { Petani }\end{array}$ & $\begin{array}{l}\text { Sesudah } \\
\text { Pa- } \\
\text { guyuban } \\
\text { Petani }\end{array}$ \\
\hline $\begin{array}{l}\text { Tingkat } \\
\text { kesempatan } \\
\text { kerja }\end{array}$ & Sangat Mudah & - & - \\
& Mudah & - & 15 \\
& Biasa saja & 49 & 35 \\
Tingkat & Sulit & 1 & - \\
pendapatan & Sangat Sulit & - & - \\
& Sangat Cukup & - & - \\
& Biasa Saja & - & 7 \\
& Kurang & 2 & 43 \\
& Sangat Kurang & - & - \\
Tingkat & Sangat Tinggi & - & - \\
kepemilikan & Tinggi & 6 & 10 \\
& Biasa Saja & 44 & 40 \\
& Rendah & - & - \\
& Sangat Rendah & - & - \\
\hline
\end{tabular}

Tingkat pendapatan dan tingkat kepemilikan aset sebelum dan sesudah munculnya Paguyuban Petani memiliki sedikit peningkatan. Kedua variabel ini merupakan akibat langsung dari adanya pekerjaan, sedangkan Paguyuban Petani hanya memberikan akses untuk mencari pekerjaan sehingga tak terlalu berpengaruh terhadap kedua variabel tersebut. Kemunculan Paguyuban Petani membuat Lanud ATS tak 
berani lagi untuk melakukan sweeping ke rumah-rumah warga. Sehingga tidak ada lagi kerusakan dari kepemilikan aset, justru responden menyatakan bahwa kepemilikan aset mereka berubah menjadi lebih tinggi setelah adanya Paguyuban Petani.

\section{"Nteu ngaruh mereun (enggak ngaruh lah) masalah kerjaan mah ya. Biasa-biasa weh. Cuma tenang, dulu mah kemana-mana takut. Cuma sekarang mah udah banyak teman, banyak yang mimpin. Gitu." MRM, 70 tahun.}

Keseluruhan variabel tersebut dijadikan dalam satuan tingkat kesejahteraan ekonomi masyarakat. Hasil pengukuran tersebut dapat dilihat pada gambar berikut ini.

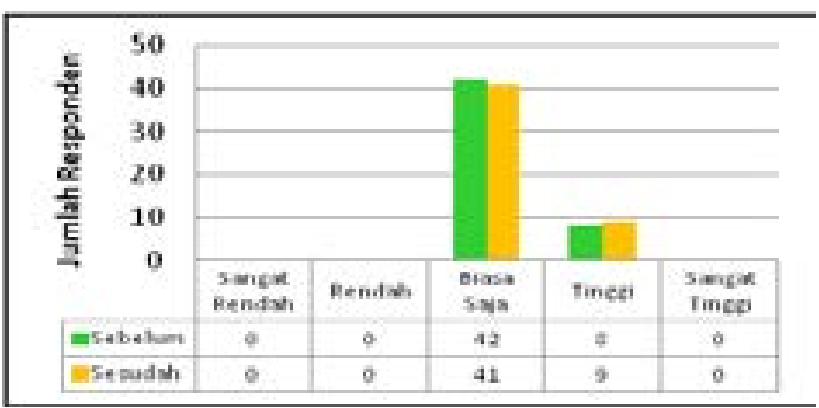

Gambar 2 Tingkat Kesejahteraan Ekonomi Masyarakat Desa Sukamulya Sebelum dan Sesudah Munculnya Paguyuban Petani Tahun 2013

Gambar di atas menunjukkan bahwa peningkatan tingkat kesejahteraan ekonomi hanya dialami oleh satu responden atau sebesar 2 persen saja dari total keseluruhan responden. Satu orang responden tersebut memiliki perubahan yang cukup besar dari ketiga variabel yang telah digabungkan. Sebagian besar responden merasa bahwa kehidupan mereka secara ekonomi tidak berubah di ketiga variabel. Umumnya perubahan hanya dirasakan pada satu variabel saja, yaitu variabel tingkat kesempatan kerja. Keberadaan Paguyuban Petani dianggap hanya fokus pada penyelesaian konflik tanah saja. Tidak ada pembukaan lapangan pekerjaan atau sejenisnya yang dilakukan oleh Paguyuban Petani terhadap masyarakat yang tergusur dari lahan mereka. Paguyuban Petani lebih dianggap sebagai pembuka akses masyarakat untuk beraktifitas kembali ke luar desa setelah terjadinya konflik.

Tahap penghitungan hubungan kedua variabel pada gambar dilakukan dengan aplikasi IBM SPSS Statistics 20 dengan uji statistik Rank Spearman. Tetapi sebelumnya untuk melihat korelasi kedua variabel, data tersebut dimasukkan ke dalam tabel tabulasi silang.

Tabel tabulasi silang di bawah menunjukkan ada 5 orang responden atau sebanyak 10 persen yang berada pada kategori yang benar yaitu kategori berhasil dalam tingkat keberhasilan gerakan Paguyuban Petani dan kategori tinggi dalam tingkat kesejahteraan ekonomi. Tabel tabulasi silang menunjukkan bahwa hubungan antara tingkat keberhasilan gerakan paguyuban petani sangat kecil atau lemah. Hasil yang didapatkan dari uji korelasi pada tabel tabulasi silang sejalan dengan hasil yang didapatkan dari uji statistik Rank Spearman. Tabel tabulasi silang di bawah menunjukkan ada 5 orang responden atau sebanyak 10 persen yang berada pada kategori yang benar yaitu kategori berhasil dalam tingkat keberhasilan gerakan Paguyuban Petani dan kategori tinggi dalam tingkat kesejahteraan ekonomi. Tabel tabulasi silang menunjukkan bahwa hubungan antara tingkat keberhasilan gerakan paguyuban petani sangat kecil atau lemah. Hasil yang didapatkan dari uji korelasi pada tabel tabulasi silang sejalan dengan hasil yang didapatkan dari uji statistik Rank Spearman.

Tabel 2. Jumlah dan Persentase Responden Paguyuban Petani Menurut Tingkat Keberhasilan Gerakan Paguyuban Petani dan Tingkat Kesejahteraan Ekonomi Desa Sukamulya Tahun 2013

\begin{tabular}{|c|c|c|c|c|c|c|c|c|}
\hline \multirow{3}{*}{$\begin{array}{l}\text { Tingkat Keber- } \\
\text { hasilan Gera- } \\
\text { kan Paguyuban } \\
\text { Petani }\end{array}$} & \multicolumn{6}{|c|}{ Tingkat Kesejahteraan Ekonomi } & \multirow{2}{*}{\multicolumn{2}{|c|}{ Total }} \\
\hline & \multicolumn{2}{|c|}{$\begin{array}{l}\text { B i a s a } \\
\text { Saja }\end{array}$} & \multicolumn{2}{|c|}{ Tinggi } & \multicolumn{2}{|c|}{$\begin{array}{l}\text { S a ng a t } \\
\text { Tinggi }\end{array}$} & & \\
\hline & $\mathrm{n}$ & $\%$ & $\mathrm{n}$ & $\%$ & $\mathrm{n}$ & $\%$ & $\mathrm{n}$ & $\%$ \\
\hline Biasa Saja & 0 & 0 & 0 & 0 & 0 & 0 & 0 & 0 \\
\hline Berhasil & 30 & 60 & 5 & 10 & 0 & 0 & 35 & 70 \\
\hline $\begin{array}{l}\text { Sangat Berha- } \\
\text { sil }\end{array}$ & 11 & 22 & 4 & 8 & 0 & 0 & 15 & 30 \\
\hline Total & 41 & 82 & 9 & 18 & 0 & 0 & 50 & 100 \\
\hline
\end{tabular}

Hasil uji dengan menggunakan aplikasi IBM SPSS Statistics 20 menunjukkan bahwa nilai korelasi yang didapatkan ialah sebesar 0.029. Nilai tersebut menyatakan bahwa terdapat korelasi atau hubungan yang sangat lemah. Nilai hitung tersebut berada diantara nilai $0-0.25$, seperti yang dijelaskan oleh Sarwono (2009) bahwa jika hasil uji berada di antara nilai tersebut maka terdapat korelasi yang sangat lemah. Nilai korelasi yang didapatkan lebih mendekati angka 0 dibandingkan dengan dengan 0.25 sehingga dapat dianggap sebagai hubungan yang sangat lemah.

Selanjutnya mengenai signifikasi dalam pengukuran kedua variabel tersebut dapat dinyatakan bahwa kedua variabel tersebut tidak signifikan. Hal tersebut dijelaskan taraf nyata yang didapatkan ialah sebesar 0.420 yang ternyata lebih besar dibandingkan dengan penggunaan taraf nyata atau $\alpha$ sebesar 1 persen atau 0.01. Berdasarkan penjelasan di atas, dapat disimpulkan bahwa antara variabel tingkat keberhasilan gerakan paguyuban petani dengan variabel tingkat kesejahteraan ekonomi masyarakat terdapat hubungan yang sangat lemah dan tidak signifikan. Jadi, dapat dikatakan bahwa hipotesis uji yang pertama untuk penelitian metode kuantitatif ditolak.

\section{Dampak Paguyuban Petani terhadap Kesejahteraan Sosial Masyarakat}

Ada tiga variabel untuk mengukur tingkat kesejahteraan sosial masyarakat yaitu tingkat kriminalisasi, hubungan dengan sesama masyarakat, dan hubungan dengan pihak lain yang berkonflik. Tingkat kriminalisasi adalah ukuran saat anggota Paguyuban Petani merasakan kekerasan baik secara fisik dan psikologis. Hubungan dengan sesama masyarakat dilihat dari kebersamaan yang diciptakan antara sesama anggota masyarakat termasuk didalamnya ada anggota Paguyuban Petani. Hubungan dengan pihak lain yang berkonflik dilihat dari kebersamaan yang terjadi antara anggota Paguyuban Petani dengan pihak lain yang terlibat konflik dengan mereka. Pengukuran dilakukan 
untuk melihat perbedaan antara tingkat kesejahteraan sosial masyarakat sebelum dan sesudah munculnya Paguyuban Petani.

Variabel tingkat kriminalisasi saat sebelum dan sesudah munculnya Paguyuban Petani menurun dengan sangat drastis. Setelah munculnya Paguyuban Petani, responden menyatakan bahwa mereka tak lagi menerima kekerasan, ancaman, maupun aksi-aksi kriminalisasi lainnya dari lanud ATS. Mereka tak berani secara terang-terangan untuk kembali melakukan aksi-aksi kekerasan terhadap masyarakat. Meskipun demikian, ternyata ada beberapa laporan dari responden yang menyatakan bahwa mereka terkadang masih mendapat "hardikan" saat lewat di depan TNI AU, terutama di daerah perumahan TNI AU. Tetapi kembali Paguyuban Petani menjadi jembatan diantara keduanya. Paguyuban Petani pernah menegur Lanud ATS sehingga "penghardikan" tersebut tak banyak berlanjut sampai saat ini.

Tabel 3. Jumlah Responden berdasarkan Variabel Tingkat Kesejahteraan Sosial Sebelum dan Sesudah Munculnya Paguyuban Petani

\begin{tabular}{|c|c|c|c|c|c|}
\hline $\begin{array}{l}\text { Vari- } \\
\text { abel Tingkat } \\
\text { Kesejahter- } \\
\text { aan Sosial }\end{array}$ & Skala & $\begin{array}{l}\text { belum } \\
\text { g u y u } \\
\text { Petani }\end{array}$ & $\begin{array}{r}\text { S e - } \\
\text { Pa- } \\
\text { b a n }\end{array}$ & $\begin{array}{l}\text { sudah } \\
\text { g u y u } 1 \\
\text { Petani }\end{array}$ & $\begin{array}{r}\text { S e - } \\
\text { Pa- } \\
\text { b a n }\end{array}$ \\
\hline \multirow{7}{*}{$\begin{array}{l}\text { Tingkat krimi- } \\
\text { nalisasi }\end{array}$} & Sangat Jarang & - & & 44 & \\
\hline & Jarang & & 10 & & 6 \\
\hline & Cukup & & 24 & & - \\
\hline & Sering & & & & \\
\hline & Sering & & 13 & & - \\
\hline & Sangat & & 2 & & - \\
\hline & Sering & & & & \\
\hline \multirow{7}{*}{$\begin{array}{l}\mathrm{H} \mathrm{u} \mathrm{b} \mathrm{u} \mathrm{n} \mathrm{g} \mathrm{a} \mathrm{n} \\
\text { dengan sesama } \\
\text { masyarakat }\end{array}$} & Sangat Baik & - & & 18 & \\
\hline & Baik & & 1 & & 31 \\
\hline & B i a s a & & 48 & & 1 \\
\hline & Saja & & & & \\
\hline & Buruk & & 1 & & - \\
\hline & Sangat & & - & & - \\
\hline & Buruk & & & & \\
\hline \multirow{3}{*}{$\begin{array}{l}\text { H u b u n g a n } \\
\text { dengan pihak } \\
\text { yang berkonf- } \\
\text { lik }\end{array}$} & Sangat baik & - & & - & \\
\hline & Baik & & - & & 4 \\
\hline & $\mathrm{B}$ i as a & & 1 & & 32 \\
\hline \multirow[t]{3}{*}{ (Lanud ATS) } & Buruk & & 46 & & 13 \\
\hline & Sangat & & 3 & & 1 \\
\hline & Buruk & & & & \\
\hline
\end{tabular}

Variabel hubungan dengan sesama masyarakat setelah munculnya Paguyuban Petani mengalami peningkatan menjadi lebih baik. Responden menyatakan bahwa Paguyuban Petani bergerak sebagai organisasi yang merangkul masyarakat Desa Sukamulya untuk ikut berpartisipasi dalam menangani konflik. Salah satu buktinya ialah, turunnya 6000 orang masyarakat untuk melakukan aksi mengangkat isu konflik ini di Jakarta. Lalu variabel hubungan dengan TNI AU juga mengalami peningkatan paling banyak dari skala buruk menjadi skala biasa saja. Responden menilai bahwa TNI AU sudah mulai kooperatif sehingga masyarakat juga mulai biasa saja saat menghadapi mereka. Responden menyatakan bahwa selama TNI AU tak lagi memojokkan mereka, maka masyarakat juga akan bersikap biasa saja. Ketiga variabel tersebut dijadikan dalam satuan tingkat kesejahteraan sosial masyarakat.

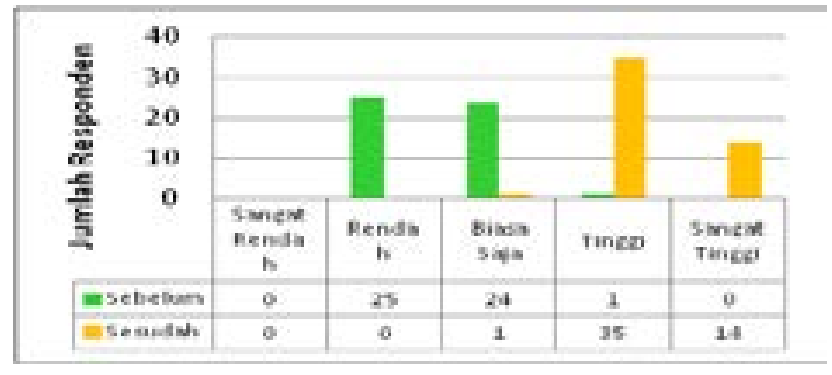

Gambar 3. Tingkat Kesejahteraan Sosial Masyarakat Desa Sukamulya Sebelum dan Sesudah Munculnya Paguyuban Petani Tahun 2013

Sesudah munculnya Paguyuban Petani, hampir seluruh responden mengalami peningkatan tingkat kesejahteraan sosial. Sebanyak 35 orang berada di dalam kategori tinggi dan 14 orang di dalam kategori sangat tinggi, serta hanya ada 1 orang dalam kategori biasa saja. Selain memperjuangkan pengembalian tanah milik masyarakat, Paguyuban Petani juga merupakan wadah masyarakat untuk mengadu dan bertugas melindungi masyarakat. Sejak munculnya Paguyuban Petani, kekerasan yang dialami masyarakat berkurang secara signifikan. Bahkan saat ini meskipun perjuangan belum selesai, tetapi masyarakat sudah sangat jarang mendapat kekerasan secara fisik maupun psikologis dari Lanud ATS.

Tahap penghitungan hubungan kedua variabel pada gambar dilakukan dengan aplikasi IBM SPSS Statistics 20 dengan uji statistik Rank Spearman. Tetapi sebelumnya untuk melihat korelasi kedua variabel, data tersebut dimasukkan ke dalam tabel tabulasi silang.

Tabel 4. Jumlah dan Persentase Responden Paguyuban Petani Menurut Tingkat Keberhasilan Gerakan Paguyuban Petani dan Tingkat Kesejahteraan Sosial Desa Sukamulya Tahun 2013

\begin{tabular}{|c|c|c|c|c|c|c|c|c|}
\hline \multirow{3}{*}{$\begin{array}{l}\text { Tingkat Ke- } \\
\text { berhasilan } \\
\text { Ge rakan } \\
\text { Paguyuban } \\
\text { Petani }\end{array}$} & \multicolumn{6}{|c|}{ Tingkat Kesejahteraan Sosial } & \multirow{2}{*}{\multicolumn{2}{|c|}{ Total }} \\
\hline & \multicolumn{2}{|c|}{$\begin{array}{l}\text { B i a s a } \\
\text { Saja }\end{array}$} & \multicolumn{2}{|c|}{ Tinggi } & \multicolumn{2}{|c|}{$\begin{array}{l}\text { S a ng a t } \\
\text { Tinggi }\end{array}$} & & \\
\hline & $\mathrm{n}$ & $\%$ & $\mathrm{n}$ & $\%$ & $\mathrm{n}$ & $\%$ & $\mathrm{n}$ & $\%$ \\
\hline Biasa Saja & 0 & 0 & 0 & 0 & 0 & 0 & 0 & 0 \\
\hline Berhasil & 1 & 2 & 30 & 60 & 4 & 8 & 35 & 70 \\
\hline $\begin{array}{l}\text { Sangat Ber- } \\
\text { hasil }\end{array}$ & 0 & 0 & 5 & 10 & 10 & 20 & 15 & 30 \\
\hline Total & 1 & 2 & 35 & 70 & 14 & 28 & 50 & 100 \\
\hline
\end{tabular}

Responden yang menyatakan bahwa paguyuban petani sudah berada dalam kategori berhasil sebanyak 30 orang berada di dalam kategori tingkat kesejahteraan sosial yang tinggi. Mereka merasa terlindungi dengan adanya 
Paguyuban Petani yang menjaga masyarakat dari berbagai bentuk tindak kekerasan. Selain itu, hubungan masyarakat juga dengan berbagai pihak juga menjadi lebih baik karena ada campur tangan dari Paguyuban Petani. Hal ini juga yang menyebabkan pada kategori gerakan paguyuban petani yang sangat berhasil, mayoritas responden sebanyak 10 orang berada dalam kategori tingkat kesejahteraan sosial sangat tinggi.

Hasil yang didapatkan dari uji korelasi pada tabel tabulasi silang juga sejalan dengan hasil yang didapatkan dari uji statistik Rank Spearman. Hasil uji dengan menggunakan aplikasi IBM SPSS Statistics 20 menunjukkan bahwa nilai korelasi yang didapatkan ialah sebesar 0.375 . Nilai tersebut menyatakan bahwa terdapat korelasi yang cukup kuat. Nilai hitung tersebut berada diantara nilai $0.25-0.5$. Sarwono (2009) menjelaskan bahwa jika hasil uji berada di antara nilai tersebut maka terdapat korelasi atau hubungan yang cukup kuat.

Soal signifikasi dalam pengukuran kedua variabel tersebut dapat dinyatakan bahwa kedua variabel tersebut signifikan. Hal tersebut dijelaskan taraf nyata yang didapatkan ialah sebesar 0.003 yang ternyata lebih kecil dibandingkan dengan penggunaan taraf nyata atau $\alpha$ sebesar 1 persen atau 0.01. Berdasarkan penjelasan di atas, dapat disimpulkan bahwa antara variabel tingkat keberhasilan gerakan paguyuban petani dengan variabel tingkat kesejahteraan ekonomi masyarakat terdapat hubungan yang cukup kuat dan signifikan. Jadi, dapat dikatakan bahwa hipotesis uji kedua untuk penelitian metode kuantitatif diterima, semakin tinggi tingkat keberhasilan gerakan perlawanan petani maka akan semakin tinggi tingkat kesejahteraan sosial masyarakat.

\section{SIMPULAN DAN SARAN}

\section{Simpulan}

Konflik terjadi di Desa Sukamulya, Kecamatan Rumpin, Kabupaten Bogor, Jawa Barat. Di desa ini terdapat konflik agraria antara masyarakat melawan negara yang diwakili oleh institusi Lanud ATS (TNI-AU). Paguyuban Petani merupakan bentuk perlawanan masyarakat Desa Sukamulya yang berbentuk sebuah organisasi. Tujuan utama dari Paguyuban Petani ialah untuk mengembalikan hak masyarakat yang telah diambil dan diklaim oleh Lanud ATS.

Perlawanan yang dilakukan oleh Paguyuban Petani dilakukan secara kolaboratif. Hasil penelitian ini menunjukkan mayoritas responden menilai bahwa Paguyuban Petani sudah berhasil sampai saat ini, meskipun belum sepenuhnya mampu mengembalikan tanah milik masyarakat dengan pembuatan sertifikat. Ada beberapa faktor penting yang menjadi kunci keberhasilan gerakan Paguyuban Petani dalam menciptakan situasi yang menguntungkan bagi mereka. Faktor tersebut antara lain kepemimpinan, kolektifitas simpul-simpul, gerakan dari Paguyuban Petani yang bersifat masif dan berkelanjutan, dan bantuan dari pihak lain yang mendukung Paguyuban Petani. Jadi, Paguyuban Petani mampu menciptakan sebuah situasi untuk menjamin kontrol atas tanah dengan melakukan pergerakan secara kolaboratif, masif, dan berkelanjutan.

Penelitian menunjukkan gerakan Paguyuban Petani yang dinilai berhasil oleh responden ternyata hanya mempunyai hubungan yang sangat lemah serta tak signifikan dengan tingkat kesejahteraan ekonomi masyarakat. Paguyuban Petani dianggap hanya berfokus pada penyelesaian konflik saja dan hanya berdampak sedikit pada terbukanya akses kesempatan kerja, serta tak berdampak pada pendapatan maupun kepemilikan aset. Berbeda dengan hasil kesejahteraan ekonomi, justru gerakan Paguyuban Petani ternyata mempunyai hubungan yang cukup kuat dan signifikan dengan tingkat kesejahteraan sosial masyarakat. Paguyuban Petani dianggap mampu dalam hal menurunkan tingkat kriminalisasi, serta peningkatan hubungan dengan sesama warga maupun dengan pihak yang berkonflik

\section{Saran}

Beberapa saran yang diajukan penulis berdasarkan hasil penelitian ini, yaitu:

1. Pemerintah terutama institusi Kementerian Keuangan, Kementerian Pertahanan, Badan Pertanahan Nasional, serta instansi-instansi terkait lainnya untuk menindaklanjuti dan menyelesaikan sampai tuntas Berita Acara Hasil Tim Verifikasi Lahan. Sehingga terjadi kondisi win-win solution antara semua pihak yang menyetujui hasil berita acara tersebut. Selain itu, masyarakat juga mendapatkan kembali hak mereka atas tanah yang terklaim.

2. Paguyuban Petani serta masyarakat Desa Sukamulya, agar tetap memperjuangkan hak mereka sampai Berita Acara Hasil Tim Verifikasi Lahan terwujud secara nyata. Sebab, masyarakat tidak akan bisa membuat sertifikat tanah sampai hasil berita acara itu dilaksanakan sepenuhnya.

3. Pemerintah perlu meninjau ulang dan menindaklanjuti mengenai kasus konflik agraria terutama yang disertai dengan kekerasan terhadap masyarakat.

\section{DAFTAR PUSTAKA}

[AGRA] Aliansi Gerakan Reforma Agraria. 2010. Perampasan Tanah : Sebab, Bentuk, Dan Akibatnya Bagi Kaum Tani. [Internet]. [27 Maret 2013]. Dapat diunduh dari: http://farmlandgrab.org/wpcontent/uploads/2010/09/Risalah-ttg-PerampasanTanah_24-Sept-2010.doc

[BKKBN] Badan Kependudukan dan Keluarga Berencana Nasional. 2011. Batasan dan Pengertian MDK. [Internet]. [13 Juni 2013]. Dapat diunduh dari : http://aplikasi.bkkbn.go.id/mdk/BatasanMDK.aspx

[BPS] Badan Pusat Statistik. 2010. Penduduk Berumur 15 Tahun Ke atas Menurut Kelompok Umur dan Lapangan Pekerjaan Utama. [Internet]. [2 April 2013]. Dapat diunduh dari: http://sp2010.bps.go.id/ index.php/site/tabel?tid $=290 \&$ wid $=0$

Fermata W. 2006. Reklaiming Tanah Sebagai Bentuk Resistensi Masyarakat Desa Hutan. [skripsi]. Bogor [ID]: Institut Pertanian Bogor. 183 hal.

Fuad FH dan Maskanah S. 2000. Inovasi Penyelesaian Sengketa Pengelolaan Sumber Daya Hutan. Bogor: Pustaka LATIN. 
Hartoyo. 2010. Involusi Gerakan Agraria dan Nasib Petani. [Disertasi]. Bogor [ID]: Institut Pertanian Bogor. 195 hal.

Landsberger HA dan Alexandrov YG. 1974. Pergolakan Petani dan Perubahan Sosial. (Alih bahasa Aswab Mahasin). Jakarta [ID]: Rajawali Press. 138 hal.

Luthfi AN. 2011. Melacak Sejarah Pemikiran Agraria. Yogyakarta [ID]: STPN Press

Luthfi AN, Fauzi M, dan Razif. 2010. Kronik Agraria Indonesia: Memperluas Imajinasi Lintas Zaman, Sektor, dan Aktor. Yogyakarta [ID]: STPN Press

Purwandari H. 2006. Perlawanan Tersamar Organisasi Petani. [Tesis]. Bogor [ID]: Institut Pertanian Bogor. 179 hal.

Rianse U dan Abdi. 2009. Metodologi Penelitian Sosial dan Ekonomi: Teori dan Aplikasi. Bandung [ID]: ALFABETA

Sarwono J. 2009. Statistik itu Mudah: Panduan Lengkap untuk Belajar Komputasi Statistik Menggunakan SPSS 16. Yogyakarta [ID]: ANDI

Sastraatmadja E. 2010. Suara Petani. Bandung [ID]: Masyarakat Geografi Indonesia

Setiawan U. 2012. Dari Konfrontasi ke Kolaborasi. [Tesis]. Bogor [ID]: Institut Pertanian Bogor. 202 hal.

Setiawan. 2007. Pendekatan Antropologi bagi Konflik Agraria. [Internet]. [29 April 2013]. Dapat diunduh dari: http://www.duniaesai.com/index. php?option $=$ com content $\&$ view $=$ article $\&$ id $=57$ :pe ndekatan-ant

Sjaf S. 2010. Batasan Definisi Petani (Peasant). [Internet]. [29 April 2013]. Dapat diunduh dari: http://www. academia.edu/2239693/Batasan_Definisi_Petani

Taib R, Sutarto E, dan Tonny F. Transformasi Gerakan Identitas Petani. J Sodality. [Internet]. [8 Maret 2013]. 4(2):239-254. Dapat diunduh dari : http:// jurnalsodality.ipb.ac.id/index.php/component/ sodality/?id=92\&task=view

Tauchid M. 2009. Masalah Agraria: Sebagai Masalah Penghidupan dan Kemakmuran Rakyat Indonesia. Savitri LA, Shohibuddin M, Saluang S, editor. Yogyakarta [ID]: STPN Press

Tim Rises Sistematis. 2009. Memahami dan Menemukan Jalan Keluar dan Masalah Agraria dan Krisis Sosial Ekologis. Bogor [ID]: Sajogyo Institute dan STPN Press

[UU] Undang-Undang Nomor 5 Tahun 1960 Tentang Peraturan Dasar Pokok-Pokok Agraria

[UU] Undang-Undang Nomor 11 Tahun 2009 Tentang Kesejahteraan Sosial

White B dan Wiradi G. 2009. Reforma Agraria dalam Tinjauan Komparatif: Hasil Lokakarya Kebijakan
Reforma Agraria di Selabintana. (Alih bahasa dari bahasa Inggris oleh Stephanus Aswar Herwinko). Bogor [ID]: Brighten Press. 144 hal. [Judul asli Agrarian Reform in Comparative Perspective: Policy Issues and Research Needs]

Wiradi G dan Makali. 2009. Bab 5 Penguasaan Tanah dan Kelembagaan. Dalam: Ranah Studi Agraria: Penguasaan Tanah dan Hubungan Agraria. Moh. Shohibuddin, editor. Yogyakarta [ID]: STPN Press

Wiradi G. 2009. Seluk Beluk Masalah Agraria, Reforma Agraria, dan Penelitian Agraria. Yogyakarta [ID]: STPN Press 